\title{
Role of Shelfbreak Upwelling in the Formation of a Massive Under-ice Bloom in the Chukchi Sea
}

\author{
Michael A. Spall ${ }^{1}$, Robert S. Pickart ${ }^{1}$, Eric T. Brugler ${ }^{1}$, G.W.K Moore ${ }^{2}$, \\ Leif Thomas ${ }^{3}$, Kevin R. Arrigo ${ }^{3}$,
}

February 2014

submitted to Deep-Sea Research II

Corresponding Author: M.A. Spall (mspall@whoi.edu)

\footnotetext{
${ }^{1}$ Woods Hole Oceanographic Institution; Woods Hole, MA 02540 USA

${ }^{2}$ University of Toronto; Toronto, OT MSS 1A1 Canada

${ }^{3}$ Stanford University, Stanford, CA 94305 USA
} 


\begin{abstract}
In the summer of 2011, an oceanographic survey carried out by the Impacts of Climate on EcoSystems and Chemistry of the Arctic Pacific Environment (ICESCAPE) program revealed the presence of a massive phytoplankton bloom under the ice near the shelfbreak in the central Chukchi Sea. For most of the month preceding the measurements there were relatively strong easterly winds, providing upwelling favorable conditions along the shelfbreak. Analysis of similar hydrographic data from summer 2002, in which there were no persistent easterly winds, found no evidence of upwelling near the shelfbreak. A two-dimensional ocean circulation model is used to show that sufficiently strong winds can result not only in upwelling of high nutrient water from offshore onto the shelf, but it can also transport the water out of the bottom boundary layer into the surface Ekman layer at the shelf edge. The extent of upwelling is determined by the degree of overlap between the surface Ekman layer and the bottom boundary layer on the outer shelf. Once in the Ekman layer, this high nutrient water is further transported to the surface through mechanical mixing driven by the surface stress. Two model tracers, a nutrient tracer and a chlorophyll tracer, reveal distributions very similar to that observed in the data. These results suggest that the biomass maximum near the shelfbreak during the massive bloom in summer 2011 resulted from an enhanced supply of nutrients upwelled from the halocline seaward of the shelf. The decade long trend in summertime surface winds suggest that easterly winds in this region are increasing in strength and that such bloom events will become more common.
\end{abstract}


Key Words: upwelling; boundary currents, shelf-basin interaction; phytoplankton blooms.

\section{Introduction}

Shelfbreak upwelling is observed in all seasons in both the Alaskan and Canadian Beaufort Seas. It is most common in the fall and winter months when Aleutian low pressure systems, passing to the south, result in easterly winds along the north slope of Alaska and Canada. Under such conditions the normally eastward-flowing Pacific water shelfbreak jet reverses to the west, and water from the interior halocline is brought onto the shelf (e.g. Pickart et al. 2009; Schulze and Pickart 2012; Williams et al. 2006). As part of this wind-driven exchange, heat and freshwater are fluxed offshore in the surface layer, while nutrients and $\mathrm{CO}_{2}$ are transported upwards and onshore. The consequences of this shelf-basin transfer are significant. Pickart et al. (2013b) demonstrated that substantial ice melt can occur due to the offshore advection of warm Pacific water, which may also influence the freshwater reservoir of the Beaufort Gyre. Mathis et al. (2012) showed that significant outgassing of $\mathrm{CO}_{2}$ to the atmosphere can take place due to the upwelling, and Pickart et al. (2013a) quantified the upward flux of nitrate into the surface layer in the vicinity of the shelfbreak. It was argued that such wind-driven transport of nutrients along the Beaufort shelf can spur primary productivity comparable to that which occurs during the summer months in the absence of storm events.

Using mooring data, Schulze and Pickart (2012) investigated the influence of pack ice on the oceanographic response to easterly winds in the Beaufort Sea. They divided the year up into three ice seasons - open water, partial ice, and full ice. Notably, upwelling occurred even when the ice concentration was $100 \%$ in the vicinity of the mooring array. The strongest response (for a given wind speed) was during the partial ice season, which is believed to be the consequence of enhanced surface stress resulting from the mobile ice keels (Pite et al. 1995; Williams et al. 2006; Pickart et al. 2013b). While the water column response was weakest for full ice cover, the strength of the reversed shelfbreak jet, as well as the value of the salinity anomaly near the upper-slope and shelf edge, was nearly comparable to that for open water, indicating that significant wind stress is transmitted through the ice to the ocean. 
Upwelling is to be expected for easterly winds because onshore transport develops at depth in response to the offshore Ekman transport near the surface. Upwelling occurs in proportion to the bottom velocity times the bottom slope. It is large near the shelfbreak because the slopes are typically steep, however it is often carried in the bottom boundary layer, which is $O(10 \mathrm{~m})$ thick. In order for nutrients to be available for primary production they must be transported into the euphotic zone, which is typically in the upper $O(20 \mathrm{~m})$ of the water column. For a narrow shelf, as in the Beaufort Sea, this cross-shelf flow in the bottom boundary layer rapidly encounters shallow water near the coast where it upwells into the surface layer and large productivity is often found. The region of strongest upwelling is typically within a baroclinic deformation radius of the coast, $\leq O(20 \mathrm{~km}),($ Allen 1976).

Comparatively little is known about upwelling along the offshore edge of the Chukchi Sea, but there are reasons to expect that it may differ from that along the Beaufort shelf. The Chukchi shelf is $O(500 \mathrm{~km})$ wide, effectively isolating the shelfbreak from the coast, while the Beaufort shelf is only $O(50 \mathrm{~km})$ wide. Furthermore, the upper continental slope of the Chukchi Sea is significantly gentler, $O(.002-.004)$, compared to that of the Beaufort Sea, which is $O(.01)$. Depending on the bottom slope and mixing strength, it is expected that the cross-shelf exchange and upwelling may be very different for wide shelves compared to narrow shelves (e.g. Estrade et al. 2008). Hence, it is not obvious that the upwelling response should be the same in the two seas, nor is it clear that similar productivity would result even if there is upwelling.

There is, however, previous evidence of upwelling along the Chukchi shelfbreak. Llinás et al. (2009) presented a hydrographic and absolute geostrophic velocity section occupied across the shelfbreak at $160^{\circ} \mathrm{W}$ (approximately $200 \mathrm{~km}$ to the west of Barrow Canyon) during a period of easterly winds in August 2004. Both the observed currents and hydrographic fields were consistent with a partially recovered shelfbreak jet near the end of an upwelling event. In particular, the isopycnals of the Atlantic water in the lower halocline were elevated in the vicinity of the upper slope, and there was a surface-intensified jet flowing to the west seaward of the shelfbreak. Furthermore, in the immediate vicinity of the shelfbreak, there was a double-peaked eastward flow structure reminiscent of the case study presented by Pickart et al. (2011); the deeper flow was akin to the "rebound jet" that consistently appears during the spin-down phase of upwelling (see also 
Nikolopoulos et al. 2009). Although not conclusive, these results strongly suggest that upwelling does occur along the Chukchi shelfbreak.

In summer of 2011 an extensive survey of the central/eastern Chukchi Sea revealed the presence of a massive phytoplankton bloom under the ice (Arrigo et al., 2012; Arrigo et al., this issue). It is believed that the thin pack ice (order $1 \mathrm{~m}$ thick), in conjunction with a preponderance of melt ponds, allowed enough sunlight to penetrate the surface water column for phytoplankton to tap nutrients and spur the production. The under-ice bloom was observed on two different transects, and in both instances the highest values of chlorophyll occurred in the vicinity of the shelfbreak. In fact, the vertically integrated chlorophyll in the second transect was one of the largest values ever observed in the global ocean (Arrigo et al., this issue). This suggests that there was a prolonged supply of nutrients to the surface layer, yet the shelfbreak here is located far from the coast where the strongest upwelling into the surface layer is expected to occur.

In this paper we propose a physical mechanism responsible for the shelfbreak "mega-bloom". The in-situ hydrographic and velocity data suggest that upwelling had occurred prior to and during the biological sampling, which is consistent with the atmospheric forcing as well. The central issue is how nutrients from the deep, offshore ocean can be introduced to the surface layer near the shelfbreak. We invoke a simple numerical model to identify the underlying cause of the bloom, using parameters appropriate to the Chukchi shelf and slope. The model suggests that, under the conditions in which the bloom was observed, upwelling and mixing in the vicinity of the shelfbreak transported nutrients from the halocline to the surface layer, consistent with the hydrographic and biological observations. We begin the paper with a short background on upwelling in the Beaufort Sea in order to provide context. This is followed by a presentation of the atmospheric circulation in the region, and the wind forcing during the specific period of the field program. Next the observational evidence for upwelling is presented along with a description of the bloom. Finally, the numerical results are used to propose a simple physical process responsible for the megabloom. 


\section{Data and Methods}

\section{a. In situ Ocean Measurements}

In summer 2011, the Impacts of Climate on EcoSystems and Chemistry of the Arctic Pacific Environment (ICESCAPE) program carried out a survey of the central and eastern Chukchi Sea aboard the USCGC Healy. The cruise took place from 28 June - 24 July. Extensive biological, ice, and physical oceanographic sampling was carried out during the cruise. For a complete description of the different measurements the reader is referred to Arrigo et al. (this issue). Here we present data from one of the ICESCAPE transects occupied from 4-8 July (Fig 1). This is the section where the largest under-ice values of chlorophyll were observed in the vicinity of the shelfbreak. The hydrographic sampling was done using a SeaBird 911+ conductivity-temperature-depth (CTD) instrument attached to a 12-position rosette with 30-liter Niskin bottles. The CTD included a WETLabs fluorometer. Water samples were analyzed for nutrient concentrations and chlorophyll. Details concerning the observational methods and instrument accuracies are presented in Arrigo et al. (this issue) and Brown et al. (submitted).

Velocity measurements were made throughout the cruise using Healy's hull-mounted $150 \mathrm{KHz}$ acoustic Doppler current profiler (ADCP). The University of Hawaii UHDAS acquisition system was used, and additional processing was done using the CODAS3 software package (see http://currents.soest.hawaii.edu). The processed velocities were subsequently de-tided using the Oregon State University model (http://volkov.oce.orst.edu/tides; Padman and Erofeeva (2004)). The accuracy of the de-tided product is estimated to be $\pm 2 \mathrm{~cm} / \mathrm{s}$.

Shipboard data from an earlier cruise in the region are analyzed as well. This was a hydrographic survey done on the USCGC Polar Star during July-August, 2002 when the atmospheric conditions were significantly different than during the ICESCAPE program. A similarly configured CTD system was used, whose set-up and instrument accuracies are described in Pickart et al. (2005a). Since the Polar Star did not have a shipboard ADCP, a dual-300 KHz RD Instruments ADCP system was attached to the rosette frame, which provided vertical profiles of velocity at the station sites. The profiles were similarly de-tided (although tidal amplitudes are small in this region), and the resulting accuracies are estimated to be $2-3 \mathrm{~cm} / \mathrm{s}$. We focus on the 2002 hydro- 
graphic transect that was located in the vicinity of the mega-bloom observed during ICESCAPE (Fig 1).

Mooring data from the Beaufort Sea are used in Section 3 to provide context for the upwelling observed on the Chukchi slope. The mooring array was part of the Shelf-Basin Interactions (SBI) program and consisted of 7 tightly spaced moorings positioned from the outer-shelf to the midslope (Fig 1). Each mooring contained a motorized CTD profiler providing vertical traces of temperature and salinity four times daily. We focus on the 5 moorings situated near the shelfbreak, each of which contained an upward-facing RD Instruments ADCP sampling hourly (300 KHz instruments were used on the shallower moorings, and $75 \mathrm{KHz}$ instruments were used on the deeper moorings). The velocity data were de-tided using the tidal amplitudes measured by the ADCPs. A thorough presentation of the mooring data, including instrument accuracies, is presented in Nikolopoulos et al. (2009) and Spall et al. (2008).

\section{b. Atmospheric Measurements and Reanalysis Fields}

Atmospheric information used in the study come from two sources. Wind data were obtained from the Pt Barrow meteorological station (Fig 1) via the National Climate Data Center (http://www.ncdc.noaa.gov/). The data were subject to a quality control procedure to remove erroneous values and interpolate over short data gaps (see Pickart et al. (2013a) for details). We also used the North American Regional Reanalysis (NARR) fields, which are a high-resolution product of the National Centers for Environmental Prediction (NCEP). The NARR invokes a newer data assimilation scheme and other modeling advances that have been developed subsequent to the global NCEP product (Mesinger et al. 2006). The space and time resolution of NARR is $32 \mathrm{~km}$

and 3 hours, respectively. The NARR wind speeds were validated against the Pt Barrow data and a small correction was applied to the NARR data (see Brugler 2013, for details). 


\section{c. Model Configuration and Forcing}

The numerical model used is the MIT general circulation model (Marshall et al. 1997). It solves the hydrostatic, primitive equations on a staggered C-grid with level vertical coordinates. A partial cell treatment of the bottom topography is accurate for steep topography in the presence of stratification. The model is two-dimensional, representing depth and offshore distance. While along-shelf variations are clearly present and likely important for many aspects of the circulation and productivity on the shelf and near the shelfbreak, the purpose of the present study is to propose a physical mechanism to explain the gross characteristics of the observed mega-bloom near the shelfbreak. As such, we have chosen to use the simplest model that contains what are believed to be the essential physics of the problem; namely, a shelf and shelfbreak, baroclinicity, and surface wind stress.

The model domain extends $864 \mathrm{~km}$ in the offshore direction with a $500 \mathrm{~km}$ wide, $50 \mathrm{~m}$ deep shelf, which transitions to a $1000 \mathrm{~m}$ deep basin over a horizontal length scale of $100 \mathrm{~km}$. The horizontal grid spacing is $1 \mathrm{~km}$ for offshore distances between $450 \mathrm{~km}$ and $550 \mathrm{~km}$. The grid spacing increases to $2 \mathrm{~km}$ for the next $50 \mathrm{~km}$ in each direction, $6 \mathrm{~km}$ for the next $300 \mathrm{~km}$, finally increasing to $10 \mathrm{~km}$ near the coast. The vertical grid spacing is $5 \mathrm{~m}$ over the upper $150 \mathrm{~m}$ depth, $10 \mathrm{~m}$ between $150 \mathrm{~m}$ and $250 \mathrm{~m}$ depth, $25 \mathrm{~m}$ between $250 \mathrm{~m}$ and $500 \mathrm{~m}$ depth, and $50 \mathrm{~m}$ between $500 \mathrm{~m}$ and $1000 \mathrm{~m}$ depth. Resolution near the shelf break is $1 \mathrm{~km}$ in the horizontal and $5 \mathrm{~m}$ in the vertical, sufficient to resolve the surface and bottom boundary layers and lateral scales that arise in the vicinity of the shelfbreak. Since we are interested in the wind-driven upwelling at depths near the shelfbreak, the model domain is limited to the upper ocean. The Coriolis parameter is $f_{0}=1.3 \times 10^{-4} \mathrm{~s}^{-1}$ and taken to be constant. Density is determined by salinity only as $\rho=$

$\rho_{0}+\mathcal{B}\left(S-S_{0}\right)$, where $\mathcal{B}=0.8 \mathrm{Kg} \mathrm{m}^{-3}$ is the haline contraction coefficient, $\rho_{0}=1026 \mathrm{Kg} \mathrm{m}^{-3}$ is a reference density, and $S_{0}=35$. The initial stratification is piecewise uniform in the vertical, $N^{2}=3 \times 10^{-5} s^{-2}$ in the upper $100 \mathrm{~m}$ and $N^{2}=1 \times 10^{-5} s^{-2}$ below that. The initial salinity profile and topography near the shelfbreak (upper $200 \mathrm{~m}$ only) are shown in Fig. 2. We have neglected to include the eastward flowing shelfbreak jet in the initial condition because prior work indicates that, under upwelling conditions, the presence of an initial eastward flow does not significantly 
influence the results (Pickart et al. 2011). The baroclinic deformation radius based on this upper ocean stratification is approximately $6 \mathrm{~km}$ and is well resolved by the model grid.

Vertical diffusion of salinity is calculated using the K-profile parameterization of Large et al. (1994). Horizontal mixing of tracers is parameterized using Laplacian mixing with a coefficient of $10 \mathrm{~m}^{2} \mathrm{~s}^{-1}$. The model incorporates second order background vertical viscosity with a coefficient of $10^{-4} \mathrm{~m}^{2} \mathrm{~s}^{-1}$. Horizontal viscosity is parameterized with a second order operator with the coefficient $A_{h}$ determined by a Smagorinsky closure as $A_{h}=\left(\nu_{s} / \pi\right)^{2} L^{2} D$, where $\nu_{s}=3$ is a nondimensional coefficient, $L$ is the grid spacing, and $D$ is the deformation rate, defined as

$D=\left[\left(u_{x}-v_{y}\right)^{2}+\left(u_{y}+v_{x}\right)^{2}\right]^{1 / 2}$, where $u$ and $v$ are the horizontal velocities and subscripts indicate partial differentiation. A linear bottom drag is included with a coefficient of $2 \times 10^{-3}$, although the results are not very sensitive to this choice. The lateral boundary conditions are no-slip for velocity and no flux for salinity.

The model is forced with a spatially uniform zonal wind stress that spins up over a few days, remains relatively steady at $\tau=-0.25 \mathrm{~N} \mathrm{~m}^{-2}$ between days 10 and 20, and then spins down again (Fig. 3). Using the formula from Large and Pond (1981), the maximum stress is equivalent to a 10 $\mathrm{m}$ wind strength of $12 \mathrm{~m} \mathrm{~s}^{-1}$. Despite the fact that the mega-bloom was situated beneath the ice cover, and the ice edge was located on the outer shelf, we do not include pack ice in the model. While there appear to be some ice-edge effects in the data, these are minor in comparison to the mega-bloom signal. In fact, the presence of variable surface stress due to the ice cannot explain the dominant hydrographic and chlorophyll signatures in the observations. As discussed above, Schulze and Pickart (2012) found that wind stress is effectively transmitted to the water column on the Beaufort slope even the presence of $100 \%$ ice cover. Given this, and our desire to consider the simplest relevant physics, we invoke a spatially uniform wind stress in the model.

\section{Context for Upwelling in the Region}

The source of the Chukchi Sea shelfbreak jet is the Pacific water that flows out of Herald Canyon, and the Beaufort Sea shelfbreak jet is fed predominantly by the Pacific water emanating from Barrow Canyon, some of which likely also passes through Herald Canyon (Fig 1). During the 
spring and early summer the predominant water mass advected by the shelfbreak jet in both seas is Pacific winter water (Pickart et al. 2005a; Spall et al. 2008; Brugler et al. submitted for publication). This water mass is generally colder than $-1.65^{\circ} \mathrm{C}$, with salinities ranging from roughly 32.5-34.2 depending on the particular year (Weingartner et al. 1998). The winter water is initially formed in the Bering Sea (e.g. Muench et al. 1988), but is further modified on the Chukchi shelf when leads and polynyas open up during the winter season (e.g. Weingartner et al. 1998; Itoh et al. 2012). During these periods, re-freezing and brine rejection de-stabilize the water column and convection occurs, which further salinifies and homogenizes the winter water.

The winter water is also characterized by elevated concentrations of nutrients, including nitrate and phosphate. This is due in part to the Bering Sea source water, particularly for the water advected in the western pathway on the Chukchi shelf (Fig 1). However, the high nutrient load is also due to recycled nutrients from the seafloor (Codispoti et al. 2005). After the summer growing season, carbon is exported to the benthos where inorganic nitrate is released into the sediments due to remineralization by bacteria. In the following winter and spring, as the dense winter water flows from Bering Strait northward over the Chukchi shelf, the bottom nutrients are re-suspended into the water column (convective events likely enhance this process). This happens for each of the flow branches in the Chukchi Sea. Accordingly, even the winter water advected along the coast of Alaska, which feeds the Beaufort shelfbreak jet, is high in nutrients.

As the sunlight returns and the pack-ice melts in late-spring and summer, a chlorophyll bloom develops in the Chukchi Sea (e.g. Sambrotto et al. 1984; Hansell et al. 1993; Hill and Cota 2005; Hill et al. 2005). This is largely spurred by the high levels of nutrients in the winter water (e.g. Brown et al., submitted). Consequently, nutrient levels are drawn down in the surface layer on the shelf (Mills et al., submitted). However, much of the nutrient load of the winter water is left untapped and is subsequently advected out of Herald and Barrow canyons (Pickart et al. 2005b, 2010) into the shelfbreak jet of the Chukchi and Beaufort Seas (Llinás et al. 2009; Pickart et al. 2013a). Various processes then transfer the nutrients into the interior basin, helping to maintain the Pacific Arctic nutricline (Jones and Anderson 1986). One prominent mechanism responsible for this transfer is eddy formation. The structure of the shelfbreak jet when it advects winter water is such that it is baroclinically unstable (Spall et al. 2008; von Appen and Pickart 2012) and numerical 
simulations indicate that eddy formation should occur (Spall et al. 2008). Such winter water eddies are observed to spawn from the current (Pickart et al. 2005b), and the Canada Basin is populated by many of these features (Plueddemann et al. 1999). When the eddies spin down their high nutrients are dispersed into the ambient water. As such, a reservior of of nutrients resides adjacent to the edges of the Chukchi and Beaufort shelves throughout the year, even after the winter water passes by seasonally in the shelfbreak jet.

Easterly winds in this region are common and upwelling occurs frequently along the shelfbreak of the Beaufort Sea. During the time of year that winter water resides in the shelfbreak jet there is typically a substantial amount of pack ice (in both the Beaufort and Chukchi Seas). To demonstrate the impact of easterly winds on the transport of winter water under these conditions, we examine an upwelling event that took place along the Beaufort shelfbreak using the SBI mooring data (see Fig 1 for the location of the array). The event occurred in early May 2003, during which time the ice concentration in the region was $100 \%$. The easterly winds lasted roughly a week, with speeds between $5-10 \mathrm{~m} / \mathrm{s}$ (Fig 4a). Using the profiling CTD data and velocity data we constructed composite vertical sections of alongstream velocity (where the alongstream angle of $135^{\circ} \mathrm{T}$ is approximately aligned along the isobaths, see Nikolopoulos et al. (2009)) and hydrographic variables (Fig 4b, c). The first composite was prior to the storm, and the second composite was near the time of peak winds (Fig 4a).

Before the onset of easterly winds the shelfbreak jet was flowing swiftly to the east, advecting winter water in its core (Fig 4b). The current was bottom intensified (consistent with the geostrophic shear) as it normally is this time of year (Nikolopoulos et al. 2009). There was a small amount of Atlantic water (warmer than $-1^{\circ} \mathrm{C}$ ) present at depth on the offshore side of the section at this time. A week later the shelfbreak jet was reversed to the west and the flow was surfaceintensified (Fig 4c). One sees that the layer of winter water was now displaced upwards onto the shelf and Atlantic water was present on the mid-slope. These composites demonstrate that the high-nutrient winter water is readily transported into the layer above $50 \mathrm{~m}$ in the vicinity of the shelfbreak. Over the course of the two-year SBI program there were 45 upwelling events, 34 of which occurred during full ice cover. Unfortunately the moored CTD profilers deployed during SBI did not sample shallower than $50 \mathrm{~m}$; the tops of the moorings were situated at $45 \mathrm{~m}$ to avoid 
damage due to ice ridging, so it is difficult to say whether this winter water reaches the surface. However, Pickart et al. (2013a) present data from a winched CTD profiler deployed in 2005-6 that extended to $10 \mathrm{~m}$ depth. This indicated that, during such upwelling events, water from the upper halocline can reach the euphotic zone in the vicinity of the shelfbreak. The water is weakly stratified at this time, suggesting that vertical mixing is strong. Furthermore, using a nitrate-density relationship, Pickart et al. (2013a) estimated that the wind-driven upward flux of nitrate is enough to spur significant chlorophyll growth in this region.

\section{Atmospheric Forcing}

The results of the previous section demonstrate that wind-driven upwelling in the Beaufort Sea transports high-nutrient Pacific winter water to the vicinity of the shelfbreak. We argue below that the same process occurs in the Chukchi Sea and that this resulted in the massive phytoplankton bloom observed during the ICESCAPE program. However, since ICESCAPE took place in JuneJuly, when the winds are climatologically weak (Pickart et al. 2013a), it is necessary to examine the atmospheric forcing at the time of the study to see if upwelling was even likely.

The winds in the region are, to first order, dictated by the relative positions and strengths of two atmospheric centers of action: the Beaufort High (BH) and Aleutian Low (AL). These are clearly seen in the mean sea level pressure (SLP) field of Fig 5a. The mean was computed for the 10-yr period 2002-11, since this encompasses the both the SBI and ICESCAPE programs considered in the present study (the same patterns exist for longer term means). The BH is more symmetric and largely confined to the Canada Basin, while the AL is more elongated and extends across the Bering Sea and Gulf of Alaska. This is because the AL is the integrated signature of individual low pressure systems that propagate eastward along the North Pacific storm track. The storms tend to intensify in the region of the Aleutian Island chain and Alaskan peninsula, which is where the lowest mean SLP is found.

Computing the analogous decadal average for the summer months only (June, July, August), one sees a very different picture. In particular, the $\mathrm{BH}$ is weaker and the AL is essentially absent (Fig 5b). Accordingly, the winds over the Chukchi Sea are quite weak. However, as discussed in 
Brugler et al. (submitted for publication) and Moore (2012), there has been a pronounced trend in the strength of the summertime winds in the region over the last decade. Fig 6 shows the summertime mean zonal wind measured at the Pt Barrow weather station each year during the past 10 years, as well as that in the vicinity of the Chukchi shelf edge computed using the NARR fields. The mean easterly winds at both locations have increased markedly over this time, reaching $4 \mathrm{~m} / \mathrm{s}$ at the end of the period. As demonstrated by Schulze and Pickart (2012), $4 \mathrm{~m} / \mathrm{s}$ is the speed at which upwelling typically commences along the Beaufort shelfbreak. This suggests that the prevailing winds in recent summers might be strong enough to induce prolonged periods of upwelling. This forcing is different than the more common scenario of stronger individual storms driving shorter duration events (the average length of an upwelling event in the 70-year climatology of Pickart et al. (2013a) is 8 days).

The atmospheric circulation in summer 2011 is consistent with the above notion of prolonged upwelling favorable conditions. The mean SLP field for that summer is strikingly different than the decadal summer average (compare Fig $5 \mathrm{~b}$ and c). There is now a pronounced signature of the AL in the northern Bering Sea, and a stronger BH as well. Together these result in enhanced easterly winds over the Chukchi and Beaufort Seas (see also Brugler et al. submitted for publication). The timeseries of zonal wind speed at Pt Barrow and along the Chukchi shelf edge (which are highly correlated, Fig 7a,b) reveal that most of July and August 2011 were subject to winds out of the east, much of the time exceeding $4 \mathrm{~m} / \mathrm{s}$ (occasionally greater than $10 \mathrm{~m} / \mathrm{s}$ ). This is in contrast to the same time period in 2002 (Fig 7c) which was characterized by periods of significant westerly winds and only brief intervals of moderate easterlies. The time of occupation of the 2011 ICESCAPE section is marked by the red lines in Fig 7a and b. One sees that the winds during the month preceding the survey were upwelling favorable, and, close to/during the occupation of the section, speeds were generally above the threshold for upwelling in the Beaufort Sea. The winds measured by Healy's meteorological sensors at the time of the bloom were somewhat stronger $(7-12 \mathrm{~m} / \mathrm{s})$ than the NARR values. This is not surprising, since the relatively coarse resolution of the reanalysis product likely leads to an underestimate of the true wind speeds. 


\section{Observational Evidence for Upwelling at the Chukchi Shelf- break}

In July 2002, during the SBI program, a hydrographic/velocity transect was occupied close to the location where the mega-bloom was observed during ICESCAPE in July 2011. As discussed above, the winds were notably different during summer 2002. The time of the SBI transect is marked in Fig 7c, and one sees that during the 10 days prior to the cruise the winds were weak, which suggests that upwelling should not have been occurring at that time. Using the lowered ADCP data we constructed a vertical section of absolute geostrophic velocity, which is shown in relation to the hydrographic fields in Fig 8a,b. In the vicinity of the shelf edge the isopycnals are sloping downward offshore and there is a bottom-intensified eastward flow. This is the signature of the Chukchi shelfbreak jet. We note also that similar transects occupied farther to the east across the Chukchi shelf/slope during the cruise showed an eastward-flowing shelfbreak jet.

The analogous set of vertical sections during the ICESCAPE program in 2011 are very different than for the SBI occupation (Fig 8c,d). While there are again downward sloping isopycnals in the vicinity of the shelfbreak, the tilt is markedly steeper. The water column in general is more weakly stratified, and there is more winter water seaward of the shelf edge. Due to the combination of the weaker ambient stratification plus the steep isopycnal tilt, the value of the buoyancy frequency $N$ near the shelfbreak is small throughout the water column (approximately $10^{-2} \mathrm{~s}^{-1}$ ). In fact there is essentially no signature of the pycnocline at stations 59 and 60, which is conducive for subsurface waters to communicate easily with the surface layer (the value of $N$ in the pycnocline away from the shelf edge is $3-5 \times 10^{-2} \mathrm{~s}^{-1}$ ). In Fig 8 the $25.5 \mathrm{~kg} / \mathrm{m}^{3}$ isopycnal is marked by the thick white line, and one sees that this isopycnal outcropped at the shelf edge in the 2011 section (in contrast to the 2002 occupation). This permitted the high nutrient winter water to reach the surface. ${ }^{1}$ The velocity field was also much different during the ICESCAPE occupation. In particular, the dominant flow at the shelfbreak was to the west and intensified near the surface. In light of the previous results in the Beaufort Sea, this combination of steeply sloped isopycnals,

\footnotetext{
${ }^{1}$ Our definition of winter water as colder than $-1.65^{\circ} \mathrm{C}$ is somewhat arbitrary; the water outcropping at the shelfbreak in Fig $8 \mathrm{c}$ (colder than $-1.60^{\circ} \mathrm{C}$ ) is clearly winter water. Where this water was found at depth during the ICESCAPE survey (and previous surveys) it contained very high concentrations of nutrients.
} 
outcropping of winter water, and surface-intensified flow to the west—during a period of easterly winds - strongly suggests that shelfbreak upwelling was occurring in the Chukchi Sea prior to the occupation of the ICESCAPE transect.

The full ICESCAPE transect, including additional variables, is shown in Fig 9. Marked on the figure is the ice concentration at each station. These values were obtained either visually from the ship or using high-resolution satellite data. One sees that, shoreward of the ice edge, there is warm water residing above the winter water, and both water types are being advected to the east in a jet of water (between stations 65-72). This outer shelf jet is a combination of water from the two western flow branches of Pacific water in the Chukchi Sea, which is shown schematically in Fig 1. Such a scheme is consistent with observations from Herald Canyon (Pickart et al. 2010) as well as the other ICESCAPE transects (Pickart et al., submitted). The outer shelf jet is distinct from the shelfbreak current. The low values of ice concentration aligned with the outer shelf jet, coincident with the warmest temperatures (see Fig 9b,c), suggests that the warm water in the jet melted a swath of pack ice. This is consistent with previously observed and modeled melt-back patterns on the Chukchi shelf (Spall 2007).

Both the fluorescence and chlorophyll sections (Fig 9e,f) indicate the presence of the megabloom at the shelfbreak. In particular, note the elevated values of chlorophyll at stations 59-61. This is precisely where the winter water outcropped. Furthermore, the highest chlorophyll value is at station 60 where the buoyancy frequency was weakest throughout the water column. An upward-directed plume of high nitrate (Fig 9d) is also located at this station, but the near-surface values have been depleted (dissolved oxygen values in the surface layer are elevated in the vicinity of the shelfbreak, not shown). For a detailed description of the mega-bloom the reader is referred to Arrigo et al. (this issue). There are, however, two additional intriguing features of the vertical sections that we mention here. The first is that the mega-bloom at the shelfbreak extends all the way to the bottom (this is seen in the fluorescence as well). As detailed in Arrigo et al. (this issue), the phytoplankton cells throughout the water column here are healthy, estimated to be only 1-2 days old. Since healthy phytoplankton sinks at only 1-2 m/day (Eppley et al. 1967), it means that some physical mechanism efficiently transported the chlorophyll to depth. We note that the hydrographic characterstics of the deep part of the chloropyll plume are similar to those higher in the water 
column inshore of the shelfbreak. The second feature of note is the region of enhanced chlorophyll near the bottom on the outer shelf (stations 68-69), which is located beneath the pycnocline in a region of weak stratification. Again, sinking of phytoplankton cannot explain this feature.

To summarize, there is compelling observational evidence that the mega-bloom observed during the ICESCAPE program was largely the result of shelfbreak upwelling. The winds were easterly for most of the month leading up to the occupation of the transect and were of sufficient strength to promote upwelling; the shelfbreak jet was reversed; the isopycnals near the shelf edge were strongly sloped towards the surface; and the high-nutrient winter water outcropped at the shelfbreak-exactly where the mega-bloom occurred. We note, however, that the bloom may not have been initiated by the upwelling. As detailed above, there are pathways of winter water on the shelf and shelfbreak during this time of year, and they appear to trigger blooms (other smaller blooms on the shelf were observed during ICESCAPE). We surmise that the shelfbreak upwelling provided a sustained supply of nutrients from offshore that prolonged the bloom and resulted in the extraordinary levels of chlorophyll observed at this location. Despite our observational evidence, several important questions remain to be answered. In particular: Why was the upwelling localized to the shelfbreak? What brought the nutrients to the surface layer? Why did the bloom extend so deep into the water column? And what was the nature of the deep chlorophyll maximum on the outer shelf? We now address these questions using an idealized numerical model.

\section{The Physical Mechanism for the Shelfbreak Upwelling}

The numerical model described in Section 2c was initialized at rest using the stratification shown in Fig. 2 and run for a period of 30 days subject to the wind stress indicated in Fig. 3. Sections of across-shelf velocity, along-shelf velocity, and salinity on day 20 are shown in Fig. 10. This is shortly after the wind has begun to decrease. The offshore velocity in the surface Ekman layer of $O\left(5 \mathrm{~cm} \mathrm{~s}^{-1}\right)$ is clear in the upper 30-40 m (Fig. 10a). There is onshore flow in the bottom boundary layer, which is $O(20) \mathrm{m}$ thick. It is important to note that the zero-line of the offshore flow is deeper over the sloping bottom than it is over the shelf. This is because the Ekman layer

over the shelf extends deep enough so that it interacts directly with the bottom boundary layer. This 
will occur provided that the wind stress is sufficiently strong or the shelf is sufficiently shallow. As will be demonstrated below, this is the basic driving mechanism for the supply of nutrients to the upper ocean. The along-shelf velocity is westward everywhere and nearly uniform except in the bottom boundary layer, where it decreases to zero, and near the shelfbreak, where it is a maximum at the surface (Fig. 10b).

The onshore flow in the bottom boundary layer has advected the deep, high salinity water upward towards the shelfbreak (Fig. 10c). Near the shelfbreak the high salinity water extends to the surface. The initial stratification in the upper $50 \mathrm{~m}$ has been eroded throughout the domain due to mechanically-driven turbulent mixing, resulting in a sharp halocline near $50 \mathrm{~m}$ depth offshore of the shelfbreak. This mixing is also responsible for transporting the high salinity water near the shelfbreak all the way to the surface (where the vertical velocity goes to zero), although vertical advection must also be important at depth since the vertical mixing does not extend deeper than 50 m.

The wind-driven cross-shelf circulation is more clearly demonstrated by considering the overturning streamfunction on day 16 (Fig. 11). We show the circulation at this earlier time period, when the wind is strong, in order to best demonstrate the advection that leads to the modified salinity field at the end of the forcing period shown in Fig. 10. The maximum strength of the overturning is equivalent to $1 \mathrm{~Sv}$ per $500 \mathrm{~km}$ of along-shelf distance. There is offshore flow in the surface Ekman layer and onshore flow in the bottom boundary layer. There is also weak onshore flow throughout the water column over the sloping bottom, which feeds into the bottom boundary layer. Near the shelfbreak, approximately $35 \%$ of the onshore transport in the bottom boundary layer separates from the bottom and upwells into the surface Ekman layer. This is also where the high salinity water penetrates to the surface.

The salinity field further evolves as the wind spins down. Fig. 12 shows the salinity on day 30, after the winds have ceased. The salinity maximum near the surface has shifted slightly offshore, advected by the Ekman transport at the tail end of the storm, but remains largely as it was 10 days earlier. The high salinity in the bottom boundary layer has been advected farther onshore. This onshore transport near the bottom has persisted longer than the surface wind stress because the cross-shore pressure gradient, driven largely by the sea surface tilt, decays more slowly than the 
forcing. As a result of this cross-shelf advection, the density field near the shelfbreak now has two weakly stratified regions, one near the surface and one near the bottom, separated by a thin highly stratified layer.

The model salinity (equivalent to density) distribution at the end of the storm shows many similarities with the observed density field from ICESCAPE (Fig 9). Specifically, in the ICESCAPE section there is high salinity water present on the outer shelf in a weakly stratified layer above the bottom. Near the shelfbreak there is a region of weakly stratified, high salinity water in the upper layer, where some of the isohalines outcrop. Shoreward of this, the surface and bottom boundary layers are separated by a thin region of increased stratification. All of these featurs are present in the model salinity section on day 30 (Fig. 12). Unlike the model, however, the observations do not show a well developed bottom boundary layer over the slope.

The model salinity fields during and after the storm clearly indicate that there is significant exchange between the deep ocean, the shelf, and the surface mixed layer. To investigate this further, and help interpret the observed distributions of fluorescence/chlorophyll, we introduced two passive tracers in the model. The first tracer is initialized at a value of 1 below $100 \mathrm{~m}$ with a transition to zero at depths less than $50 \mathrm{~m}$. This is intended to represent the deep source of nitrate in the winter water and will be referred to as the nutrient tracer. It is advected and diffused in the same way as salinity, but is otherwise unforced. After 20 days this tracer looks much like the salinity field (Fig. 13a). It remains near zero everywhere in the surface layer except in the vicinity of the shelfbreak, where large values extend to the surface.

The second tracer is introduced to represent fluorescence or chlorophyll, and will be called the productivity tracer. It is initially zero everywhere and set to the value of the nutrient tracer at the surface as the field evolves. In this way it represents a substance that is generated only when high nutrient water reaches the surface. This of course is not an accurate representation of a fully interactive ecosystem model, but does provide a useful indicator of where growth resulting from high nutrient waters that reach the surface will be subsequently distributed by the flow field. The productivity tracer on day 20 shows a narrow column of high values extending from a maximum value at the surface down to the shelfbreak, nearly coincident with the region of weakly stratified, high salinity water (Fig. 13b). 
On day 30 the nutrient tracer shows a similar evolution as found for salinity (Fig. 14a). The high values at the surface have been advected slightly offshore while the high values at depth have been advected onto the outer shelf. The productivity tracer (Fig. 14b) also shows the effect of this differential advection. The high values remain in the shallow weakly stratified region but, because the bottom boundary layer has continued to advect deep water onshore, the values in the bottom boundary layer are low at and offshore of the shelfbreak. The high values that were near the shelfbreak have now been transported onto the outer shelf in the weakly stratified bottom boundary layer.

The model productivity tracer at the end of the storm shows several similarities with the observed fluorescence and chlorophyll data. In the observations (Fig 9e,f) there are high values near the surface just offshore of the shelfbreak in the weakly stratified mixed layer. There is also a patch of enhanced productivity near the bottom on the outer shelf, just onshore of the shelfbreak in the weakly stratified bottom boundary layer. This patch lies below a layer of enhanced stratification, suggesting that is was not locally formed because the stratification isolates this layer from the surface. These two regions of high productivity appear to be connected by a thin filament of high values along a layer of enhanced stratification. There is also a region offshore of this high patch in the bottom boundary layer that has high nutrients but low productivity. Each of these features is found in the model fields, suggesting that the basic mechanism responsible for the observed bloom is represented in the model.

There is one main area of disagreement between the model and observations. The observed plume of high fluorescence and chlorophyll that extends all the way to the bottom just offshore of the shelfbreak (station 60, Fig 9e,f) is not really found in the model productivity tracer. Although the model tracer does show penetration down to the top of the bottom boundary layer, it remains within the unstratified mixed layer. The data suggest that this phytoplankton must have been advected from the near surface within a few days, indicating a vertical velocity of $O\left(20 \mathrm{~m} \mathrm{day}^{-1}\right)$. There are two possible reasons for this discrepency, both having to do with the two-dimensional configuration of the model. The observed high productivity lies on the anticyclonic (shoreward) side of a narrow, deep eastward flow (Fig 9c). It is difficult to determine from our synoptic velocity section whether this is simply the shelfbreak jet beginning to re-establish itself, or if this is the 
signature of the transient rebound jet that is known to occur near the end of an upwelling event in the Beaufort Sea. Pickart et al. (2011) show that the rebound jet results from along-shelf variation in the wind stress and fast propagation of the sea surface height signal as the wind decreases. Either way, this deep eastward flow should persist for longer than an inertial period, leading to divergence in the cross-slope flow of the bottom boundary layer on the shoreward side of the feature. This in turn will drive local downwelling into the bottom boundary layer in the region of the anticyclonic vorticity of strength $\zeta H / 2$, where $\zeta$ is the relative vorticity and $H$ is the thickness of the bottom boundary layer (Pedlosky 1987). Taking typical values of $\zeta=0.1 \mathrm{~m} \mathrm{~s}^{-1} / 2 \times 10^{4} \mathrm{~m}=5 \times 10^{-6} \mathrm{~s}^{-1}$ and $H=20 \mathrm{~m}$ gives a vertical velocity of $O\left(5 \mathrm{~m}\right.$ day $\left.^{-1}\right)$, smaller than but of similar magnitude to what is required to explain the observations. The other possibility is that the mixed layer at one time did penetrate down to the bottom on the outer shelf and that the plant matter was mixed to depth (which happens very quickly) instead of being advected down. If the flow is three dimensional, the nearly vertical isopycnals are susceptible to baroclinic instability, which would lead to a rapid restratification of the mixed layer (Boccaletti et al. 2007) and result in high values deep in the water column below the stratified fluid.

A detailed study of the interaction between surface and bottom boundary layers is explored for a wide range of topographies by Estrade et al. (2008). In our case, the shelfbreak upwelling is a result of the overlap between these two boundary layers on the shallow shelf. The offshore transport in the surface Ekman layer is required to balance the vertical gradient of the turbulent shear stress. In the deep ocean, the stress goes to zero before the bottom is felt, so the Ekman transport per unit along-shelf distance is given by

$$
\Psi=\frac{\tau}{\rho_{0} f_{0}}
$$

where $\tau$ is the surface wind stress, $\rho_{0}$ is a reference density, and $f_{0}$ is the Coriolis parameter. However, over the shelf, the stress decreases away from the surface but does not go all the way to zero before the bottom boundary layer in encountered, where the stress begins to increase again. ${ }^{2}$ Hence the offshore transport in the surface Ekman layer over the shelf is less than it is in the deep

\footnotetext{
${ }^{2}$ In steady state the surface and bottom stresses are equal.
} 
ocean. This difference in the offshore transport is supplied by upwelling at the shelfbreak, which is the transition between the shallow shelf and the deep ocean.

The amount of upwelling is determined by the degree of overlap of the surface and bottom boundary layers over the shelf. The depth of the boundary layers typically scales as $\delta=$ $0.4\left(\tau / \rho_{0}\right)^{1 / 2} / f_{0}$ (Grant and Madsen 1986). For $\tau=0.25 \mathrm{~N} \mathrm{~m}^{-2}$, the value of $\delta$ is $48 \mathrm{~m}$, similar to the depth of zero offshore velocity over the slope in Fig. 10a. Sufficiently weak winds, or a deep shelf, will result in a distinct separation of the surface and bottom boundary layers and will eliminate ability of the shelfbreak upwelling to extend out of the bottom boundary layer and reach the euphotic zone. In contrast, complete overlap, such that the stress is independent of depth, would result in no cross-shelf transport over the shelf and complete upwelling of the bottom boundary layer at the shelfbreak.

\section{Conclusions}

We have proposed a physical mechanism for the massive under-ice phytoplankton boom observed in summer 2011 near the shelfbreak in the central Chukchi Sea. The winds during the month preceeding the observations were predominantly out of the east, providing conditions favorable for upwelling nutrient-rich Pacific winter water from the interior halocline onto the shelf. Hydrographic observations are consistent with this upwelling scenario. A two-dimensional ocean model run under similar forcing conditions resulted in upwelling onto the outer shelf, as expected, but also produced enhanced vertical transport into the surface Ekman layer at the shelfbreak. It was demonstrated that this enhanced upwelling is a consequence of the interaction of the surface Ekman layer with the bottom boundary layer over the shelf. Such upwelling into the surface layers is expected for strong enough winds, or a sufficiently shallow shelf, so that the surface and bottom boundary layers overlap on the shelf. Subsequent vertical mixing transports this deep, nutrient-rich water all the way to the surface, where it is available for phytoplankton growth. Idealized nutrient and cholophyll tracers in the model produced many similarities with the observed nitrate, fluorescence, and chlorophyll fields, supporting the model interpretation. This agreement suggests that ice, which was present over the bloom, does not play a critical role in the upwelling event. How- 
ever, it is likely that ice edge effects, and their influence on surface stress and buoyancy fluxes, can be important under some circumstances.

Trends in the near surface winds over the past decade indicate that such strong, upwelling favorable winds are becoming more common over the Chukchi Sea. In combination with a reduced ice cover, it is thus expected that large bloom events, as observed in 2011, will become more likely in the future. This could result in further increases in phytoplankton primary production in the Chukchi Sea, which has already experienced a greater than $40 \%$ increase in productivity since 1998 (Arrigo et al., in press). This enhanced shelf productivity is likely to support a richer benthic ecosystem but could also lead to enhanced sediment denitrification, resulting in a loss of fixed nitrogen to ecosystems downstream. The changes in Arctic marine ecosystems resulting from increased nutrient flux at the shelfbreak are difficult to predict but warrant further attention.

\section{Acknowledgments.}

The authors wish to thank Frank Bahr, who processed the vessel-mounted ADCP data on the 2011 cruise, and Dan Torres, who processed the lowered ADCP data on the 2002 cruise. This study was supported by the National Science Foundation under Grant OCE-0959381 (MAS), and by the Ocean Biology and Biogeochemistry Program and the Cryosphere Science Program of the National Aeronautic and Space Administration under Award NNX10AF42G (RSP;KRA). GWKM was supported by the Natural Sciences and Engineering Research Council of Canada. ETB was supported by the U. S. Navy. 


\section{References}

Allen, J. S., 1976: Some aspects of the forced wave response of stratified coastal regions. Journal of Physical Oceanography, 6, 113-119.

Boccaletti, G., R. Ferrari, and B. Fox-Kemper, 2007: Mixed layer instabilities and restratification. Journal of Physical Oceanography, 37, 2228-2250.

Brugler, E. T., 2013: Interannual variability of the Pacific water boundary current in the Beaufort Sea. Master's thesis, Massachusetts Institute of Technology and Woods Hole Oceanographic Institution, Cambridge/Woods Hole, MA, 120 pp.

Brugler, E. T., R. S. Pickart, G. W. K. Moore, S. Roberts, T. J. Weingartner, and H. Statscewich, submitted for publication: Seasonal to interannual variability of the Pacific water boundary current in the Beaufort Sea. Progress in Oceanography.

Codispoti, L. A., C. Flagg, V. Kelly, and J. H. Swift, 2005: Hydrographic conditions during the 2002 SBI process experiments. Deep Sea Research II, 52, 3199-3226.

Eppley, R. W., R. W. Holmes, and J. D. H. Strickland, 1967: Sinking rates of marine phytoplankton measured with a fluorometer. J. Exp. Biol. Ecol., 1, 191-208.

Estrade, P., P. Marchesiello, A. C. de Verdiere, and C. Roy, 2008: Cross-shelf structure of coastal upwelling: A two-dimensional extension of ekman's theory and a mechanism for inner shelf upwelling shut down. Journal of Marine Research, 66, 589-616.

Grant, W. D. and O. S. Madsen, 1986: The continental-shelf bottom boundary layer. Ann. Rev. Fluid Mech., 18, 265-305.

Hansell, D. A., T. E. Whitledge, and J. J. Goering, 1993: Patterns of nitrate utilization and new production over the Bering-Chukchi shelf. Continental Shelf Research, 13, 601628.

Hill, V. and G. Cota, 2005: Spatial patterns of primary production on the shelf, slope and basin of the western Arctic in 2002. Deep Sea Research II, 52, 3344-335. 
Hill, V., G. Cota, and D. Stockwell, 2005: Spring and summer phytoplankton communities in the Chukchi and eastern Beaufort Seas. Deep Sea Research II, 52, 3369-3385.

Itoh, M., K. Shimada, T. K. amd F. McLaughlin, E. Carmack, and S. Nishino, 2012: Inter-annual variability of Pacific winter water inflow through Barrow Canyon from 2000 to 2006. Journal of Oceanography, 68, 575592.

Jones, E. P. and L. G. Anderson, 1986: On the origin of the chemical properties of the Arctic Ocean halocline. Journal of Geophysical Research, 91, 10759-10767.

Large, W. G., J. C. McWilliams, and S. C. Doney, 1994: Oceanic vertical mixing: A review and a model with a nonlocal boundary layer parameterization. Reviews of Geophysics, 32, 363-403.

Large, W. G. and S. Pond, 1981: Open ocean momentum flux measurements in moderate to strong winds. Journal of Physical Oceanography, 11, 324-336.

Llinás, L., R. S. Pickart, J. T. Mathis, and S. L. Smith, 2009: Zooplankton inside an arctic cold-core eddy: Probable origin and fate. Deep Sea Research II, 56, 1290-1304.

Marshall, J., C. Hill, L. Perelman, and A. Adcroft, 1997: Hydrostatic, quasi-hydrostatic, and nonhydrostatic ocean modeling. Journal of Geophysical Research, 102, 5733-5752.

Mathis, J. T., R. S. Pickart, R. H. Byrne, C. L. McNeil, G. W. K. Moore, L. W. Juranek, S. Liu, J. Ma, R. A. Easley, M. M. Elliot, J. N. Cross, S. C. Reisdorph, F. Bahr, J. Morison, T. Lichendorf, and R. A. Feely, 2012: Storm-induced upwelling of high pCO2 waters onto the continental shelf of the western Arctic Ocean and implications for carbonate mineral saturation states. Geophysical Research Letters, 39, L07606, doi:10.1029/2012GL051574.

Mesinger, F., G. DiMego, E. Kalnay, K. Mitchell, P. C. Shafran, and Coauthors, 2006: North American regional reanalysis. Bulletin of the American Meteorological Society, 87, 343-360.

Moore, G. W. K., 2012: Decadal variability and a recent amplification of the summer Beaufort Sea High. Geophysical Research Letters, 39, doi:10.1029/2012GL051570.

Muench, R. D., J. D. Schumacher, and S. A. Salo, 1988: Winter currents and hydrographic conditions on the northern central Bering Sea shelf. Journal of Geophysical Research, 93, 516-526. 
Nikolopoulos, A., R. S. Pickart, P. S. Fratantoni, K. Shimada, D. J. Torres, and E. P. Jones, 2009: The western arctic boundary current at $152^{\circ} \mathrm{W}$ : Structure, variability, and transport. Deep Sea Research II, 56, 1164-1181.

Padman, L. and S. Erofeeva, 2004: A barotropic inverse tidal model for the Arctic Ocean. Geophysical Research Letters, 31, L02303, doi:10.1029/2003GL019003.

Pedlosky, J., 1987: Geophsyical Fluid Dynmaics. Springer-Verlag, New York, NY, Second edition.

Pickart, R., L. M. Schulze, G. W. K. Moore, M. A. Charette, K. R. Arrigo, G. van Dijken, and S. L. Danielson, 2013a: Long-term trends of upwelling and impacts on primary productivity in the Beaufort Sea. Deep Sea Research I, 79, 106-121.

Pickart, R., M. A. Spall, and J. T. Mathis, 2013b: Dynamics of upwelling in the Alaskan Beaufort Sea and associated shelf-basin fluxes. Deep Sea Research I, 76, 35-51.

Pickart, R. S., G. W. K. Moore, D. J. Torres, P. S. Fratantoni, R. A. Goldsmith, and J. Yang, 2009: Upwelling on the continental slope of the Alaskan Beaufort Sea: Storms, ice, and oceanographic response. Journal of Geophysical Research, 114, C00A13, doi:10.1029/2208JC005009.

Pickart, R. S., L. J. Pratt, D. J. Torres, T. E. Whitledge, A. Y. Proshutinsky, K. Aagaard, T. A. Agnew, G. W. K. Moore, and H. J. Dail, 2010: Evolution and dynamics of the flow through Herald Canyon in the western Chukchi Sea. Deep Sea Research II, 57, 5-26.

Pickart, R. S., L. J. Pratt, S. Zimmermann, and D. J. Torres, 2005a: Flow of winter-transformed water into the western Arctic. Deep Sea Research II, 52, 3175-3198.

Pickart, R. S., M. A. Spall, G. W. K. Moore, T. J. Weingartner, R. A. Woodgate, K. Aagaard, and K. Shimada, 2011: Upwelling in the Alaskan Beaufort Sea: Atmospheric forcing and local versus non-local response. Progress in Oceanography, 88, 78-100, doi:10.1016/j.pocean.2010.11.005.

Pickart, R. S., D. J. Torres, and P. S. Fratantoni, 2005b: The east Greenland spill jet. Journal of Physical Oceanography, 35, 1037-1053. 
Pite, H. D., D. R. Topham, and B. J. van Hardenberg, 1995: Laboratory measurements of the drag forces on a family of two-dimensional ice keel models in a two-layer flow. Journal of Physical Oceanography, 25, 3007-3031.

Plueddemann, A., R. Krishfield, and C. Edwards, 1999: Eddies in the beaufort gyre. OceanAtmosphere-Ice Interactions (OAII) All Hands Meeting.

Sambrotto, R. N., J. J. Goering, and C. P. McRoy, 1984: Large yearly production of phytoplankton in the western Bering Sea. Science, 225, 1147-1155.

Schulze, L. M. and R. S. Pickart, 2012: Seasonal variation of upwelling in the Alaskan Beaufort Sea: Impact of sea ice cover. Journal of Geophysical Research, 100, in press.

Spall, M. A., 2007: Circulation and water mass transformation in a model of the Chukchi Sea. Journal of Geophysical Research, 112, C05025, doi:10.1029/2005JC003364.

Spall, M. A., R. S. Pickart, P. S. Fratantoni, and A. J. Plueddemann, 2008: Western arctic shelfbreak eddies: Formation and transport. Journal of Physical Oceanography, 38, 1644-1668.

von Appen, W.-J. and R. S. Pickart, 2012: Two configurations of the western Arctic shelfbreak current in summer. Journal of Physical Oceanography, 42, 329-351.

Weingartner, T. J., D. J. Cavalieri, K. Aagaard, and Y. Sasaki, 1998: Circulation, dense water formation, and outflow on the northeast chukchi shelf. Journal of Geophysical Research, 103, $7647-7661$.

Williams, W. J., E. C. Carmack, K. Shimada, H. Melling, K. Aagaard, R. W. Macdonald, and R. G. Ingram, 2006: Joint effects of wind and ice motion in forcing upwelling in Mackenzie Trough, Beaufort sea. Continental Shelf Research, 26, 2351-2366. 


\section{List of Figures}

1 Circulation schematic for the Chukchi and western Beaufort Seas, including geographical place names. The two transects considered in the study, ICESCAPE 2011 and SBI 2002, are indicated, as is the SBI mooring array. . . . . . . . . . . . . . . . . . . . . 29

2 Initial salinity field and topography near the shelfbreak. . . . . . . . . . . 30

3 Strength of the zonal wind stress applied uniformly over the model domain for the 30 day simulation. 31

4 Upwelling event in the Beaufort Sea in May 2003. (a) Timeseries of zonal wind speed from the Pt Barrow weather station. Easterly winds are shaded grey. The time periods of the two composites in (b) and (c) are marked by the red lines. (b) Vertical sections from the SBI mooring array at $152^{\circ} \mathrm{W}$ before the event. The sections are an average from 28 April 1200Z-1800Z. The left-hand panel is alongstream velocity $(\mathrm{cm} / \mathrm{s})$ and the right-hand panel is potential temperature $\left({ }^{\circ} \mathrm{C}\right.$, color) overlain by potential density $\left(\mathrm{kg} / \mathrm{m}^{3}\right.$, contours). (c) Vertical sections during the event, 5 May 1200Z-1800Z.

5 Sea level pressure (mb, color and contours) overlaid by $10 \mathrm{~m}$ wind vectors, from NARR. (a) Mean for the period 2002-2011; (b) mean for the summer months of June, July, August (JJA) for the

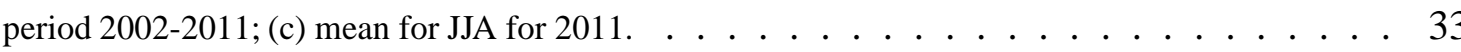

6 Mean zonal wind speed for the summer months of June, July, and August (JJA) for each year during the period 2002-2011 (black lines) and the corresponding linear fit (red lines). The solid lines are for the Pt Barrow weather station, and the dashed lines are for the NARR, averaged over a region encompassing the outer shelf and slope of the Chukchi Sea (longitude range $175-158^{\circ} \mathrm{W}$, latitude range $\left.71.5-74^{\circ} \mathrm{N}\right)$. The standard errors for the Pt Barrow data are indicated. . . . . . . . . . . . 34

7 Timeseries of zonal wind speed during the months of June and July 2011 for (a) Pt Barrow weather station, and (b) NARR, averaged over the Chukchi Sea domain noted in the caption of Fig 6. Easterly winds are shaded grey. The red lines mark the time of occupation of the ICESCAPE transect. (c) Timeseries of zonal wind speed during the months of June and July 2002 for the same NARR domain as in (b). The red lines mark the time of occupation of the SBI transect. . . . . . . 35 
8 (a,b) Vertical sections from the 2002 SBI transect. (top) Potential temperature $\left({ }^{\circ} \mathrm{C}\right.$, color) overlain by potential density $\left(\mathrm{kg} / \mathrm{m}^{3}\right.$, contours); (bottom) Absolute geostrophic velocity ( $\mathrm{cm} / \mathrm{s}$, color) overlain by potential density $\left(\mathrm{kg} / \mathrm{m}^{3}\right.$, contours). The 25.5 isopycnal is highlighted white. (c,d) Analogous vertical sections from the 2011 ICESCAPE transect. . . . . . . . . . . . . . 36

9 Vertical sections from the 2011 ICESCAPE transect. (a) Location of the stations comprising the transect. (b) Potential temperature $\left({ }^{\circ} \mathrm{C}\right.$, color) overlain by potential density $\left(\mathrm{kg} / \mathrm{m}^{3}\right.$, contours). The ice concentration at each station is marked along the top. The blue dots are visual observations from the ship, the red dots are from a Modis Terra $250 \mathrm{~m}$ resolution satellite image on 8 July (when no visual observations were taken). (c) Absolute geostrophic velocity ( $\mathrm{cm} / \mathrm{s}$, color). (c) Nitrate ( $\mu \mathrm{mol} / \mathrm{kg}$, color). Water sample positions are marked by the open circles. (d) Fluorescence (volts, color). (e) Chlorophyll $(\mu \mathrm{g} / \mathrm{l}$, color). . . . . . . . . . . . . . . . . . . . 37

10 Fields on day 20: a) cross-shore velocity $\left(\mathrm{m} \mathrm{s}^{-1}\right)$; b) alongshore velocity $\left(\mathrm{m} \mathrm{s}^{-1}\right)$; c) salinity. . . . 38

11 Transport streamfunction in the vicinity of the shelfbreak on day $16\left(m^{2} s^{-1}\right) \ldots \ldots . \ldots 39$

12 Salinity on day 30 , after the wind has ceased. . . . . . . . . . . . . . 40

13 a) Nutrient tracer on day 20; b) productivity tracer and salinity (white contours, contour interval

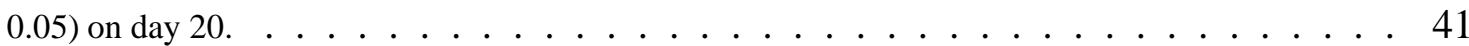

14 a) Nutrient tracer on day 30; b) productivity tracer and salinity (white contours, contour interval $0.05)$ on day $30 \ldots \ldots \ldots \ldots \ldots$. . . . . . . . . . . . . . . . . . . . . . . . . . 


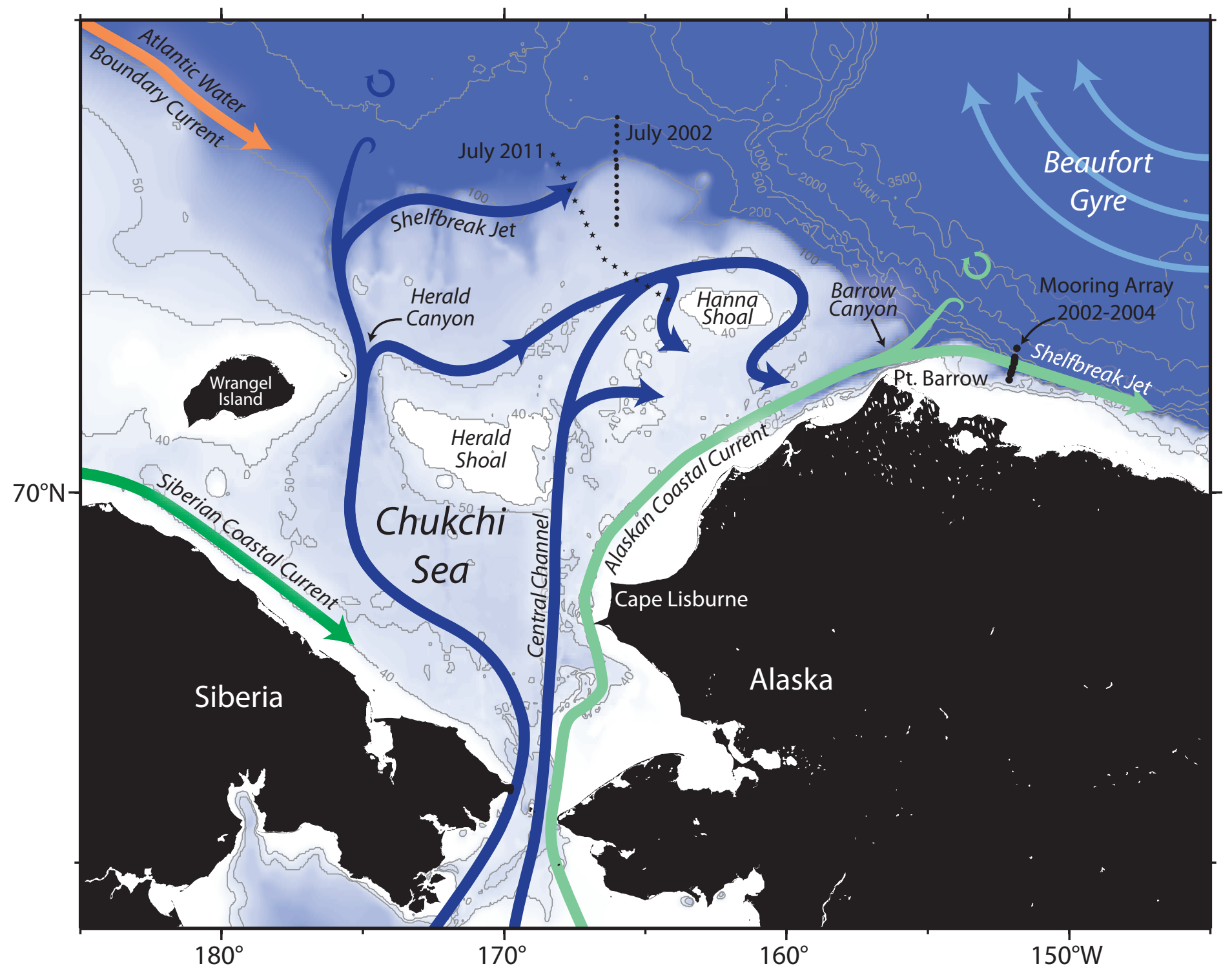

FIG. 1. Circulation schematic for the Chukchi and western Beaufort Seas, including geographical place names. The two transects considered in the study, ICESCAPE 2011 and SBI 2002, are indicated, as is the SBI mooring array. 


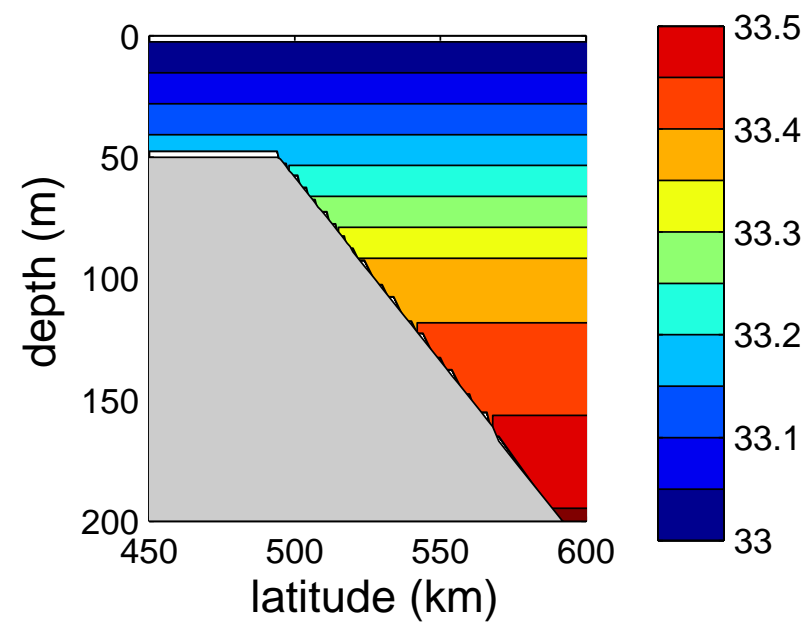

FIG. 2. Initial salinity field and topography near the shelfbreak. 


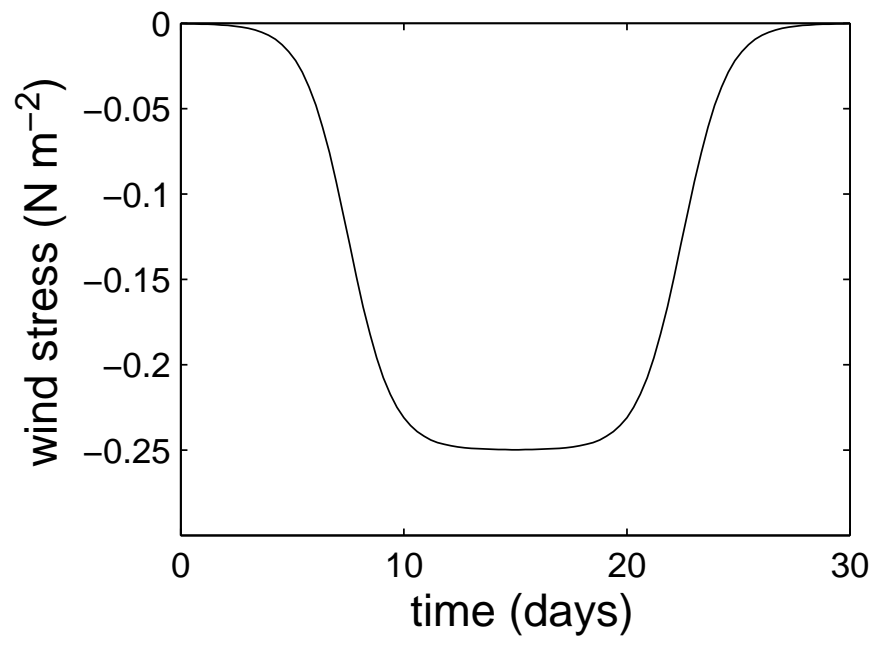

FIG. 3. Strength of the zonal wind stress applied uniformly over the model domain for the 30 day simulation. 


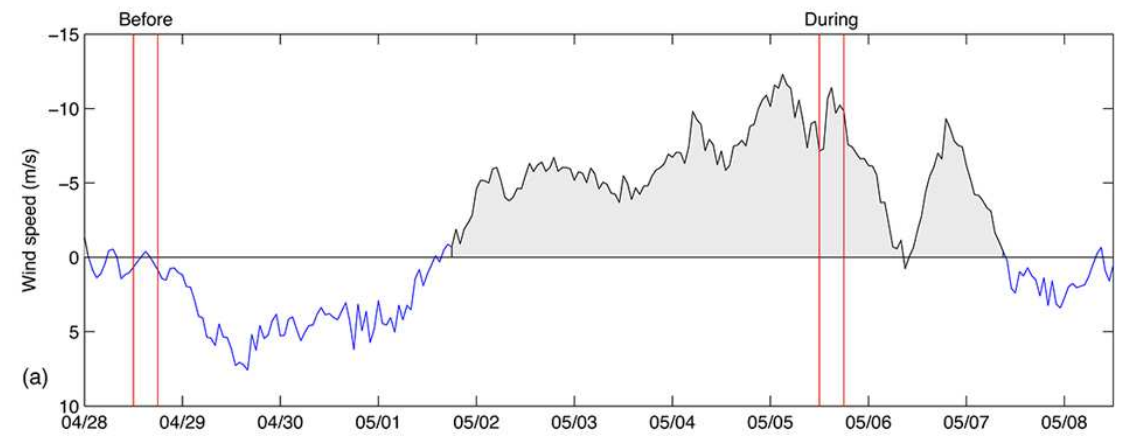

(b) Before Upwelling Event
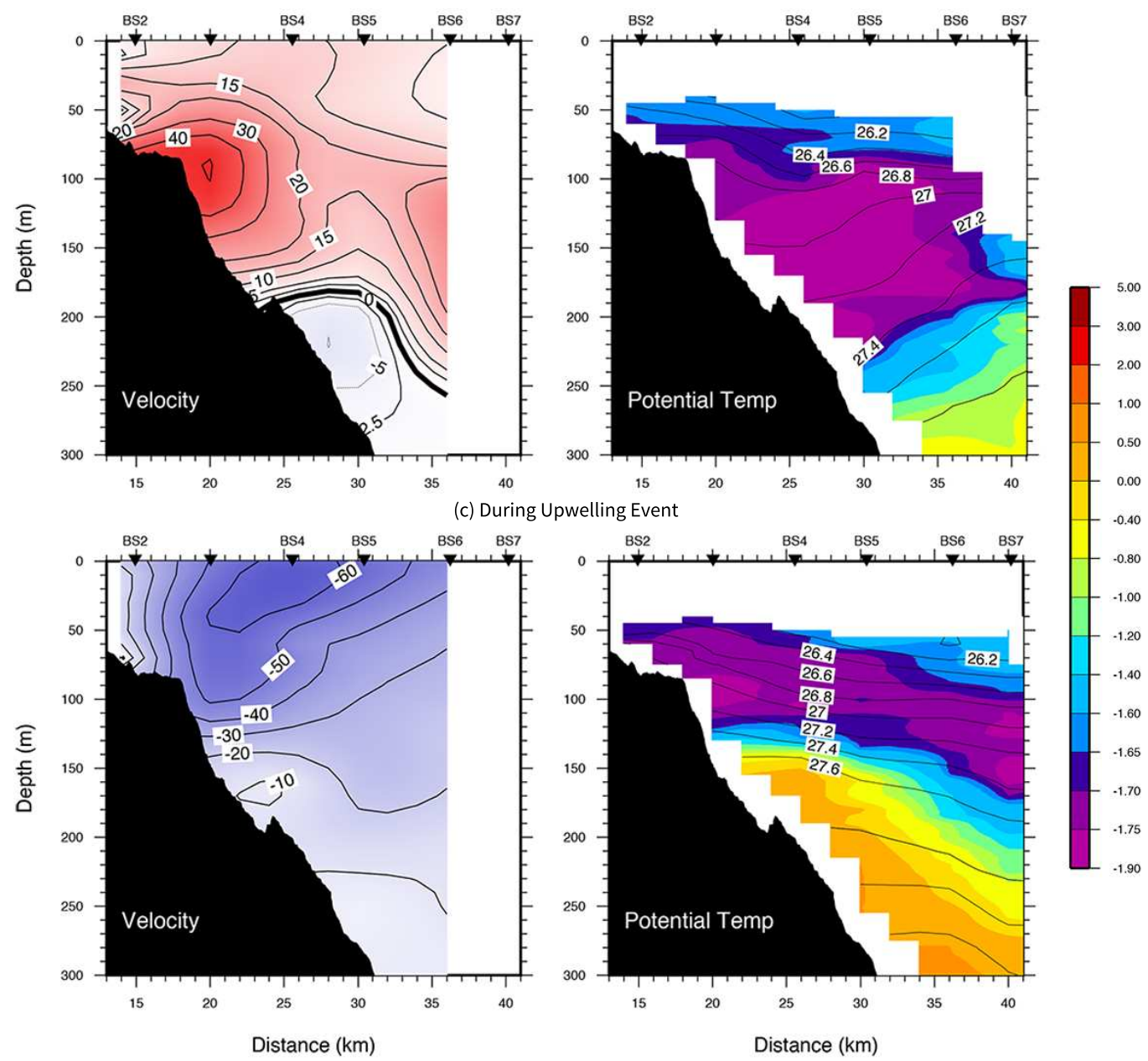

FIG. 4. Upwelling event in the Beaufort Sea in May 2003. (a) Timeseries of zonal wind speed from the Pt Barrow weather station. Easterly winds are shaded grey. The time periods of the two composites in (b) and (c) are marked by the red lines. (b) Vertical sections from the SBI mooring array at $152^{\circ} \mathrm{W}$ before the event. The sections are an average from 28 April 1200Z-1800Z. The left-hand panel is alongstream velocity $(\mathrm{cm} / \mathrm{s})$ and the right-hand panel is potential temperature $\left({ }^{\circ} \mathrm{C}\right.$, color) overlain by potential density $\left(\mathrm{kg} / \mathrm{m}^{3}\right.$, contours). (c) Vertical sections during the event, 5 May 1200Z-1800Z. 


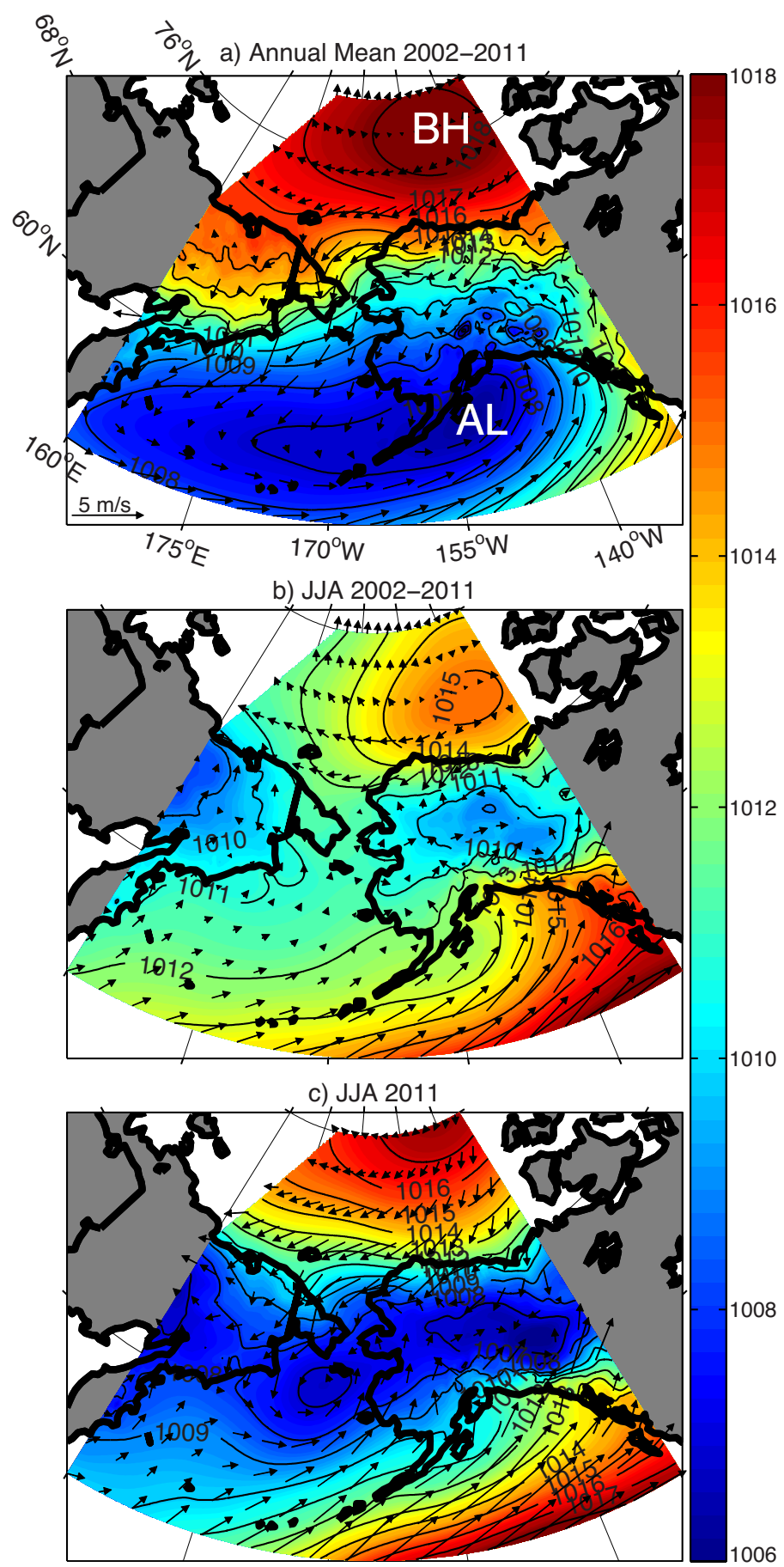

FIG. 5. Sea level pressure (mb, color and contours) overlaid by $10 \mathrm{~m}$ wind vectors, from NARR. (a) Mean for the period 2002-2011; (b) mean for the summer months of June, July, August (JJA) for the period 2002-2011; (c) mean for JJA for 2011. 


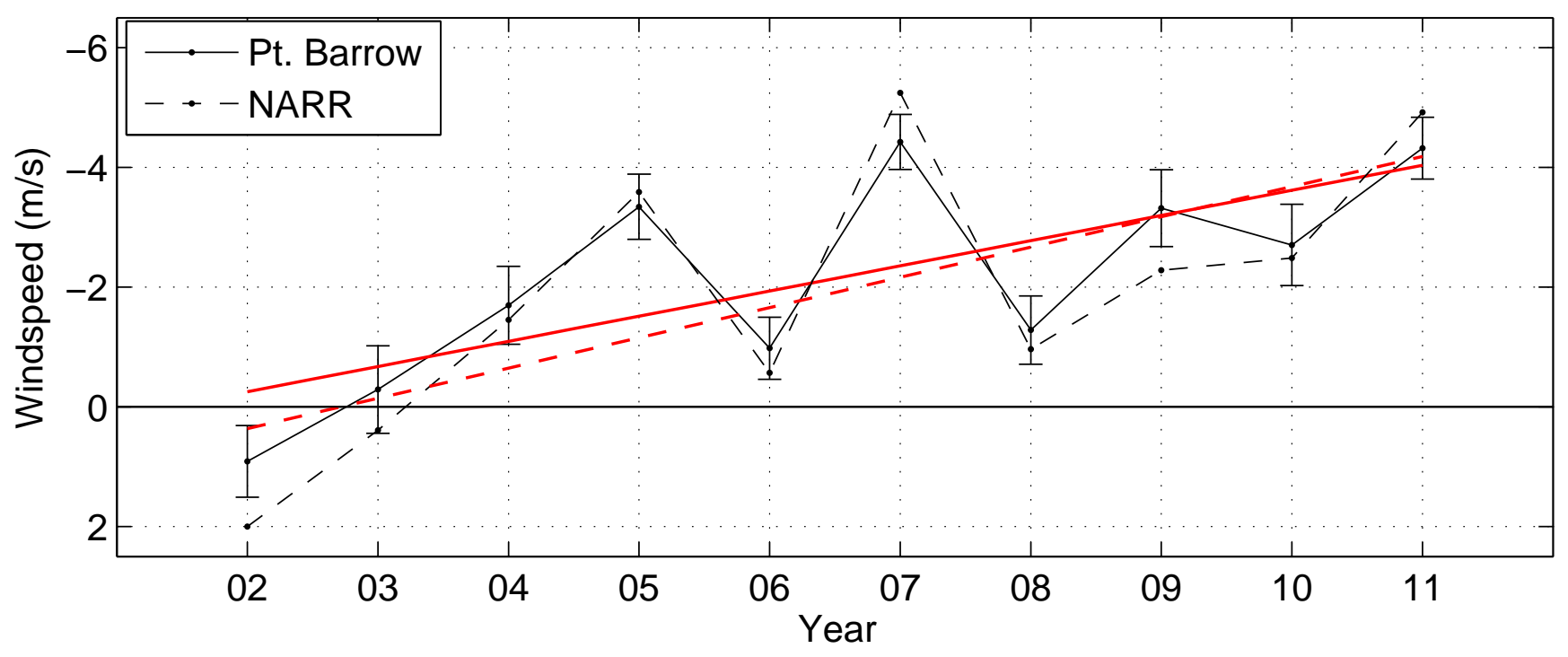

FIG. 6. Mean zonal wind speed for the summer months of June, July, and August (JJA) for each year during the period 2002-2011 (black lines) and the corresponding linear fit (red lines). The solid lines are for the Pt Barrow weather station, and the dashed lines are for the NARR, averaged over a region encompassing the outer shelf and slope of the Chukchi Sea (longitude range $175-158^{\circ} \mathrm{W}$, latitude range $71.5-74^{\circ} \mathrm{N}$ ). The standard errors for the Pt Barrow data are indicated. 
a) Pt. Barrow June-July 2011

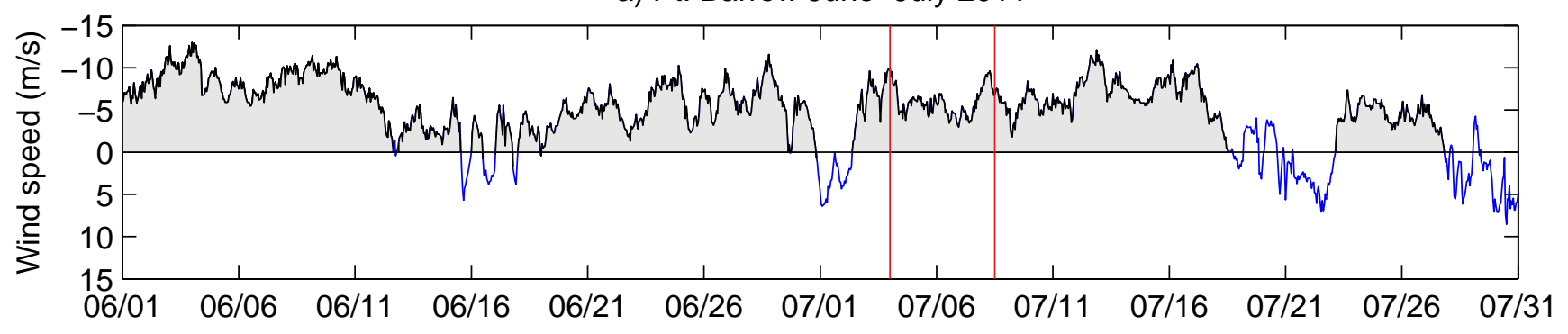

b) NARR June-July 2011

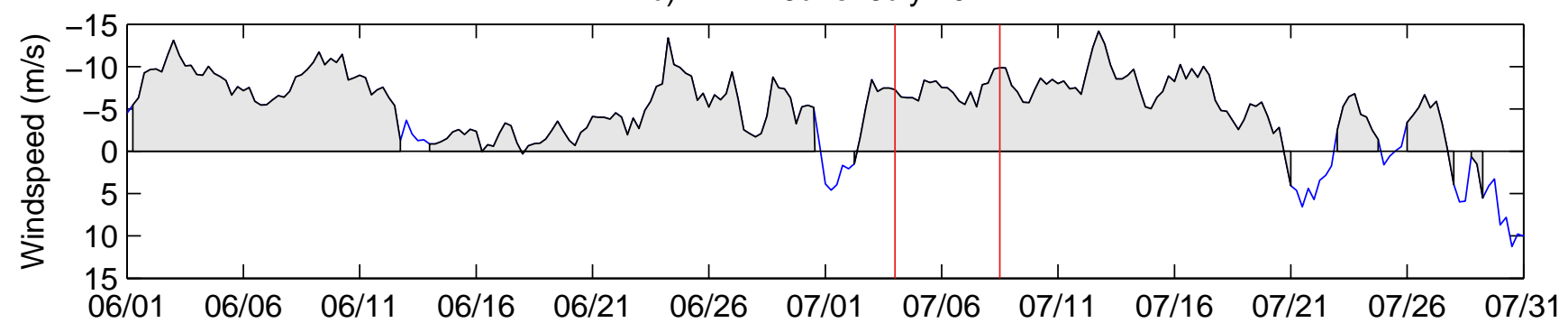

c) NARR June-July 2002

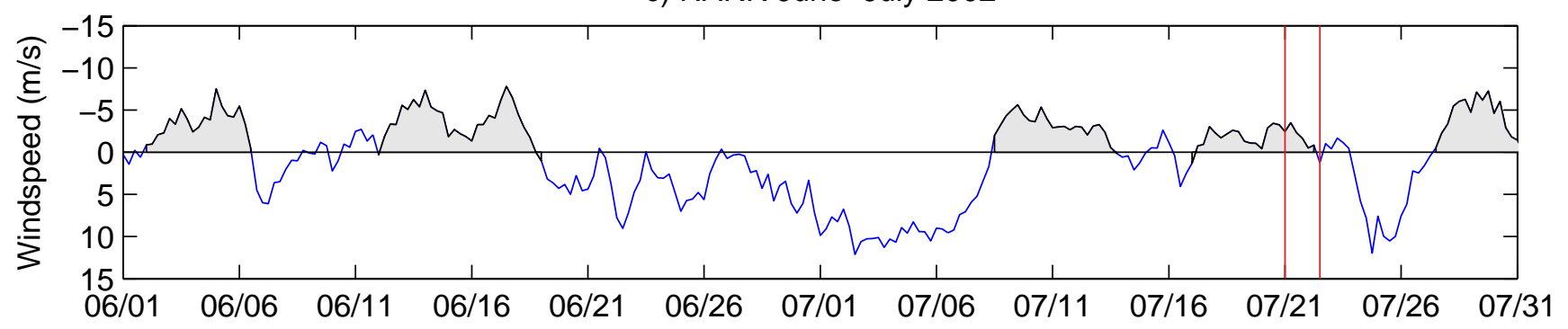

FIG. 7. Timeseries of zonal wind speed during the months of June and July 2011 for (a) Pt Barrow weather station, and (b) NARR, averaged over the Chukchi Sea domain noted in the caption of Fig 6. Easterly winds are shaded grey. The red lines mark the time of occupation of the ICESCAPE transect. (c) Timeseries of zonal wind speed during the months of June and July 2002 for the same NARR domain as in (b). The red lines mark the time of occupation of the SBI transect. 

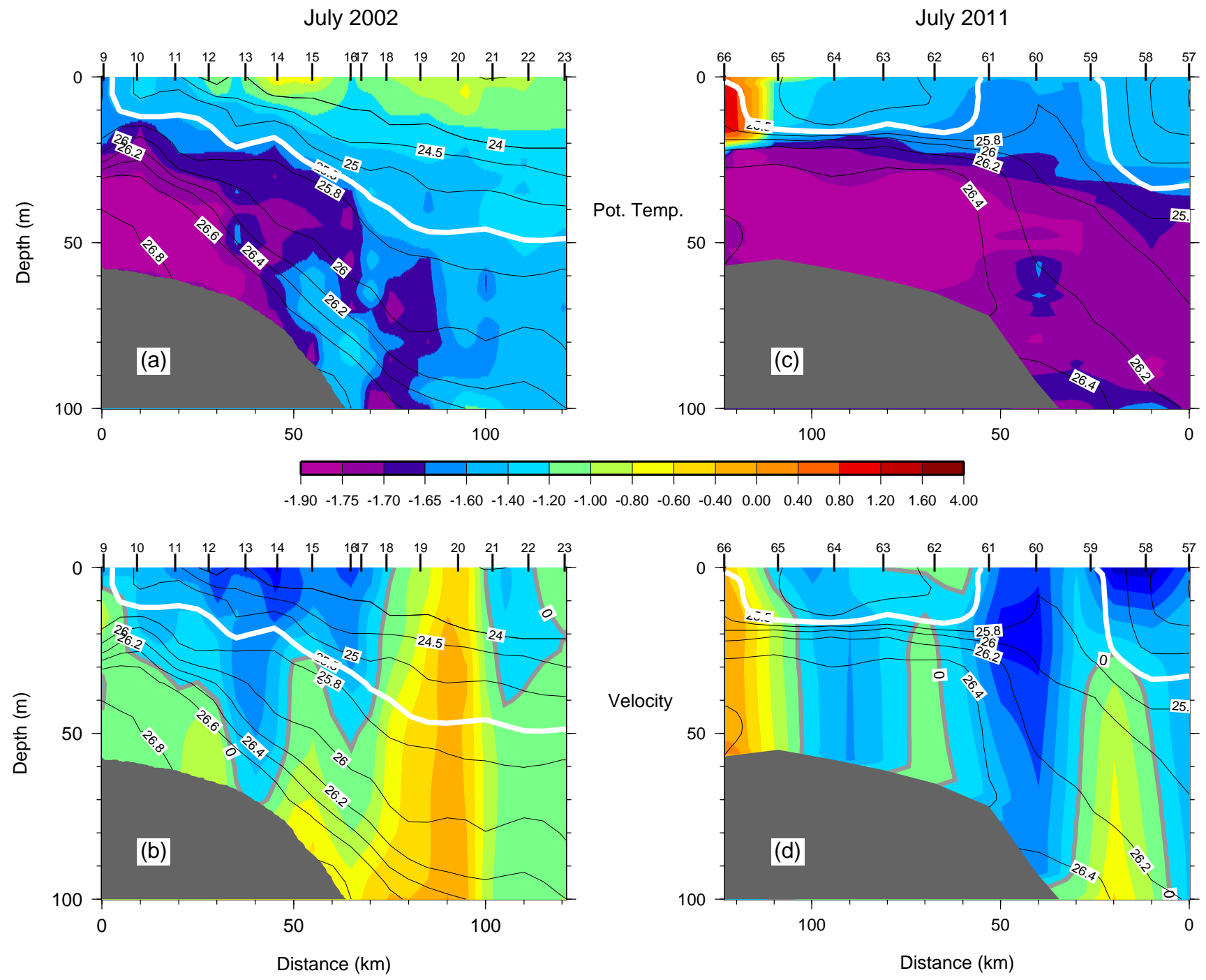

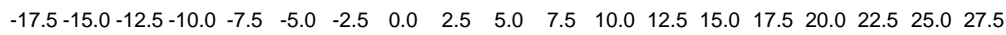

FIG. 8. (a,b) Vertical sections from the 2002 SBI transect. (top) Potential temperature $\left({ }^{\circ} \mathrm{C}\right.$, color) overlain by potential density ( $\mathrm{kg} / \mathrm{m}^{3}$, contours); (bottom) Absolute geostrophic velocity $(\mathrm{cm} / \mathrm{s}$, color) overlain by potential density $\left(\mathrm{kg} / \mathrm{m}^{3}\right.$, contours). The 25.5 isopycnal is highlighted white. (c,d) Analogous vertical sections from the 2011 ICESCAPE transect. 

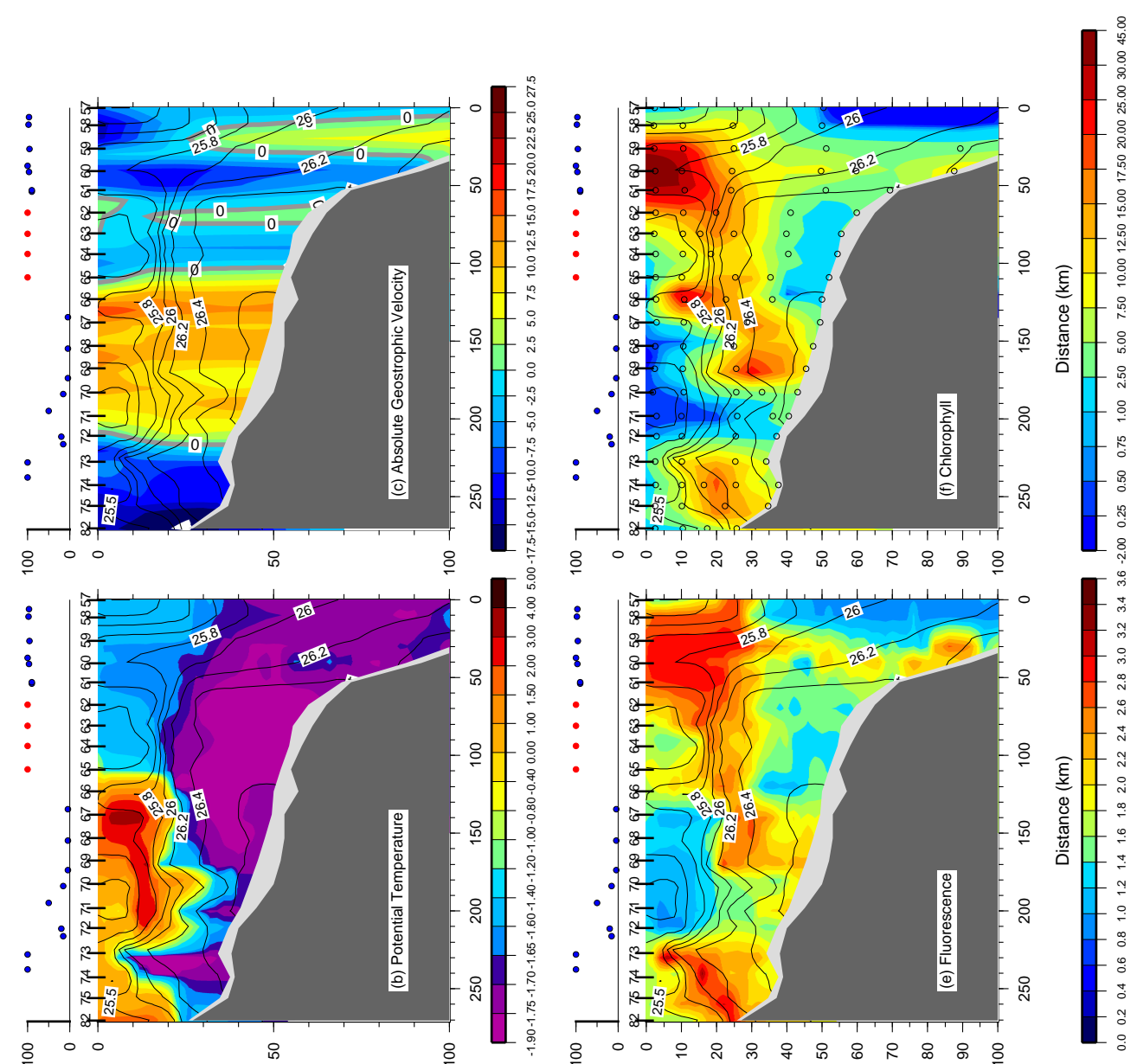

әว

(w) पldə0
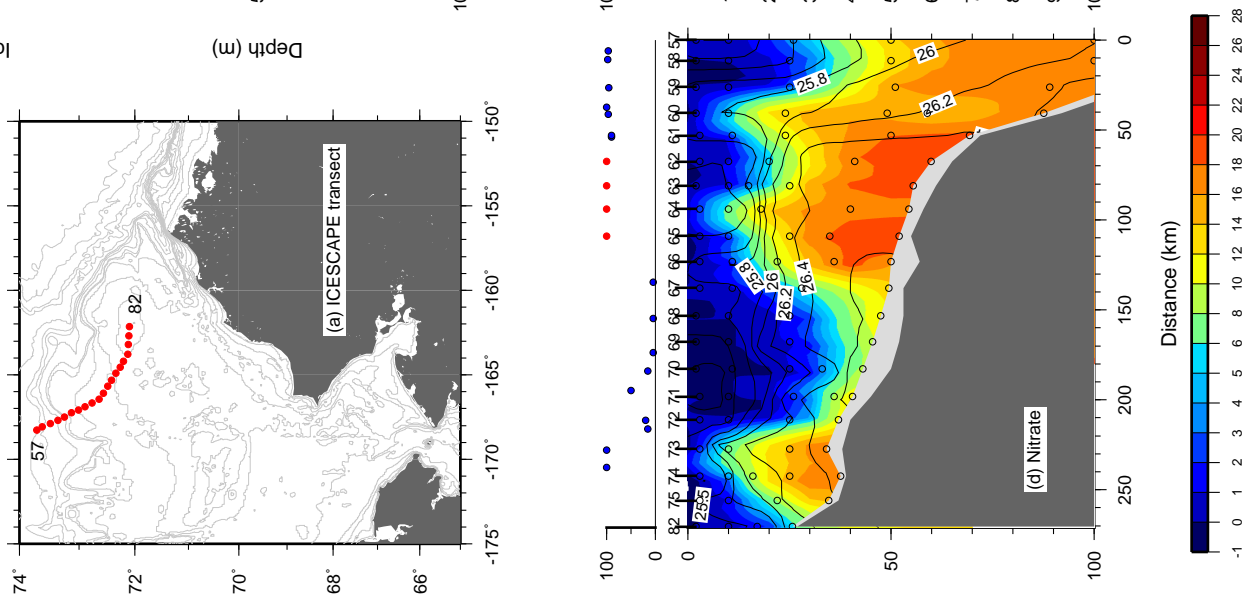

FIG. 9. Vertical sections from the 2011 ICESCAPE transect. (a) Location of the stations comprising the transect. (b) Potential temperature $\left({ }^{\circ} \mathrm{C}\right.$, color) overlain by potential density $\left(\mathrm{kg} / \mathrm{m}^{3}\right.$, contours). The ice concentration at each station is marked along the top. The blue dots are visual observations from the ship, the red dots are from a Modis Terra $250 \mathrm{~m}$ resolution satellite image on 8 July (when no visual observations were taken). (c) Absolute geostrophic velocity (cm/s, color). (c) Nitrate ( $\mu \mathrm{mol} / \mathrm{kg}$, color). Water sample positions are marked by the open circles. (d) Fluorescence (volts, color). (e) Chlorophyll ( $\mu \mathrm{g} / \mathrm{l}$, color). 

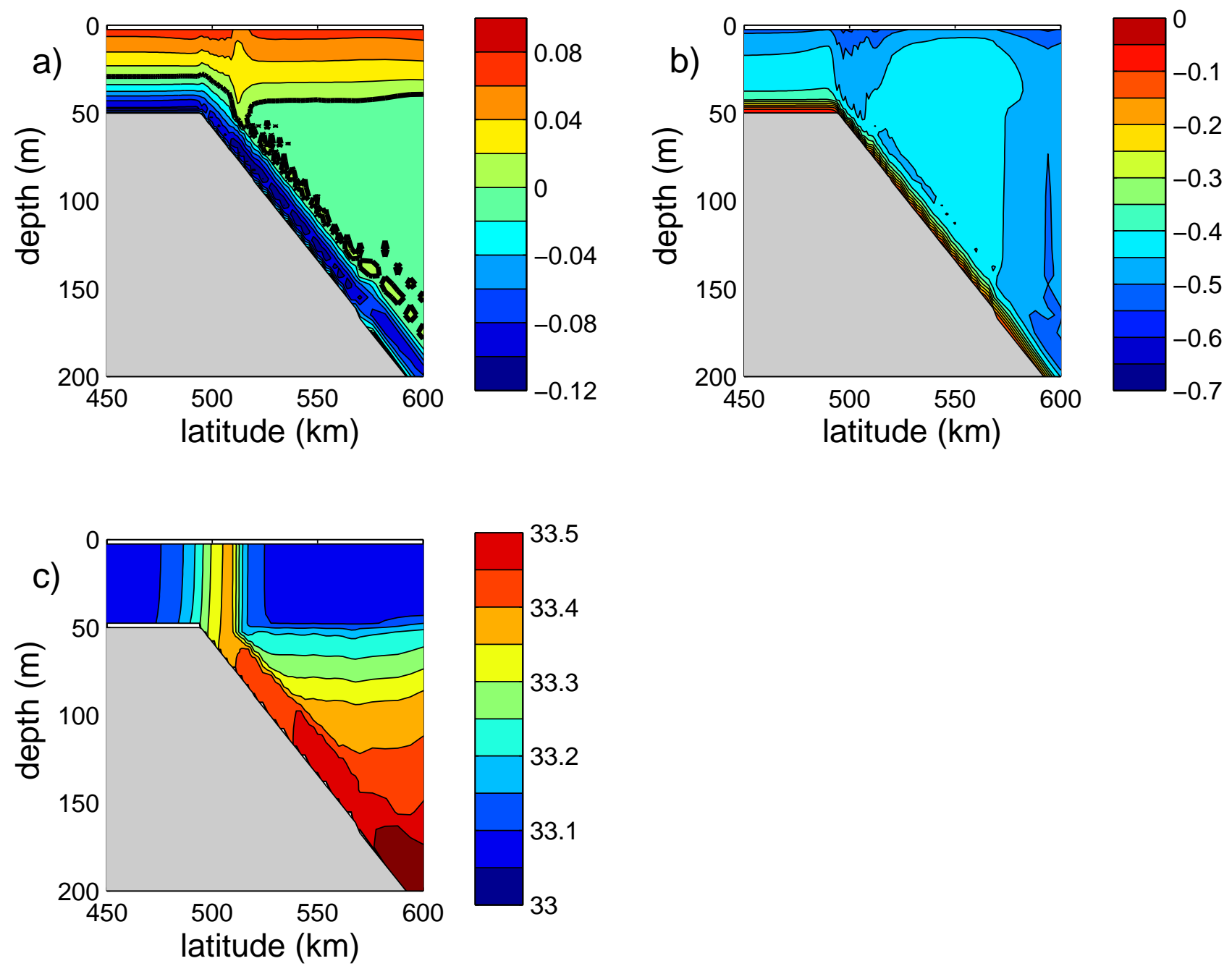

FIG. 10. Fields on day 20: a) cross-shore velocity $\left(\mathrm{m} \mathrm{s}^{-1}\right)$; b) alongshore velocity $\left(\mathrm{m} \mathrm{s}^{-1}\right)$; c) salinity. 


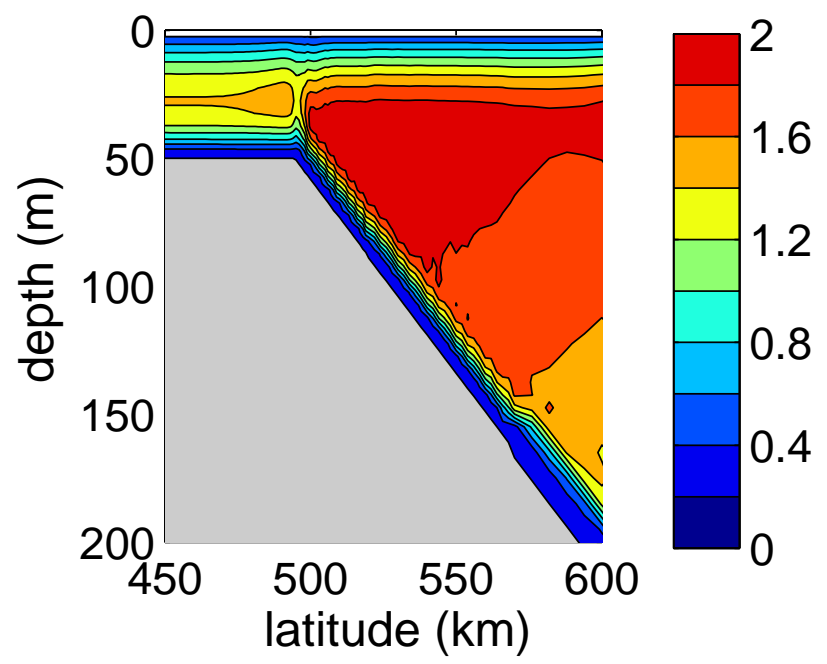

FIG. 11. Transport streamfunction in the vicinity of the shelfbreak on day $16\left(\mathrm{~m}^{2} \mathrm{~s}^{-1}\right)$. 


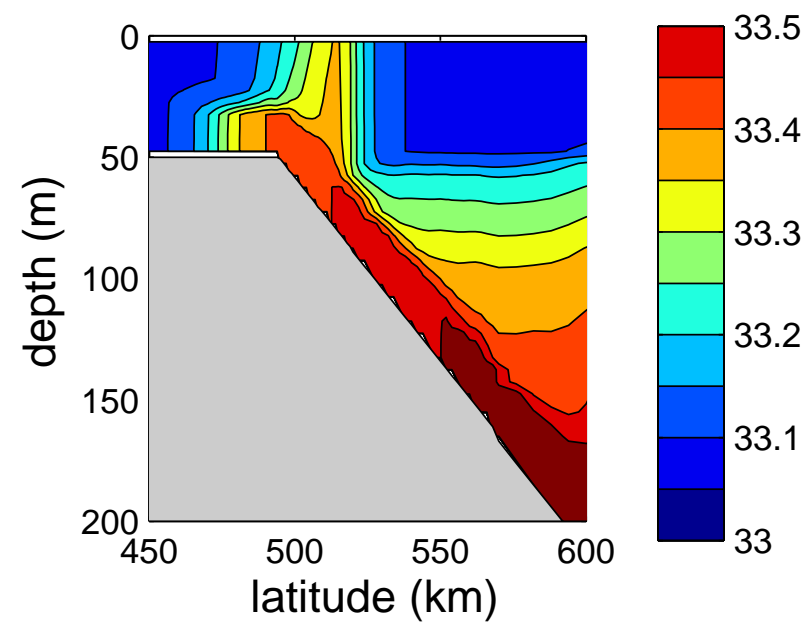

FIG. 12. Salinity on day 30, after the wind has ceased. 

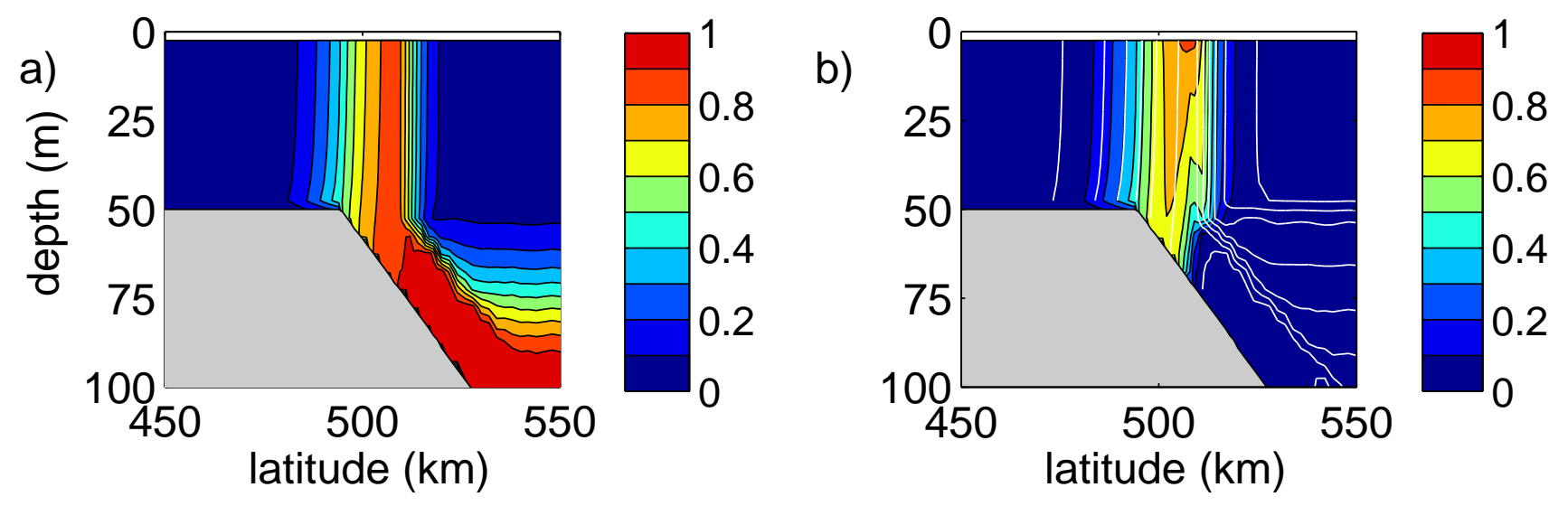

FIG. 13. a) Nutrient tracer on day 20; b) productivity tracer and salinity (white contours, contour interval 0.05) on day 20 . 

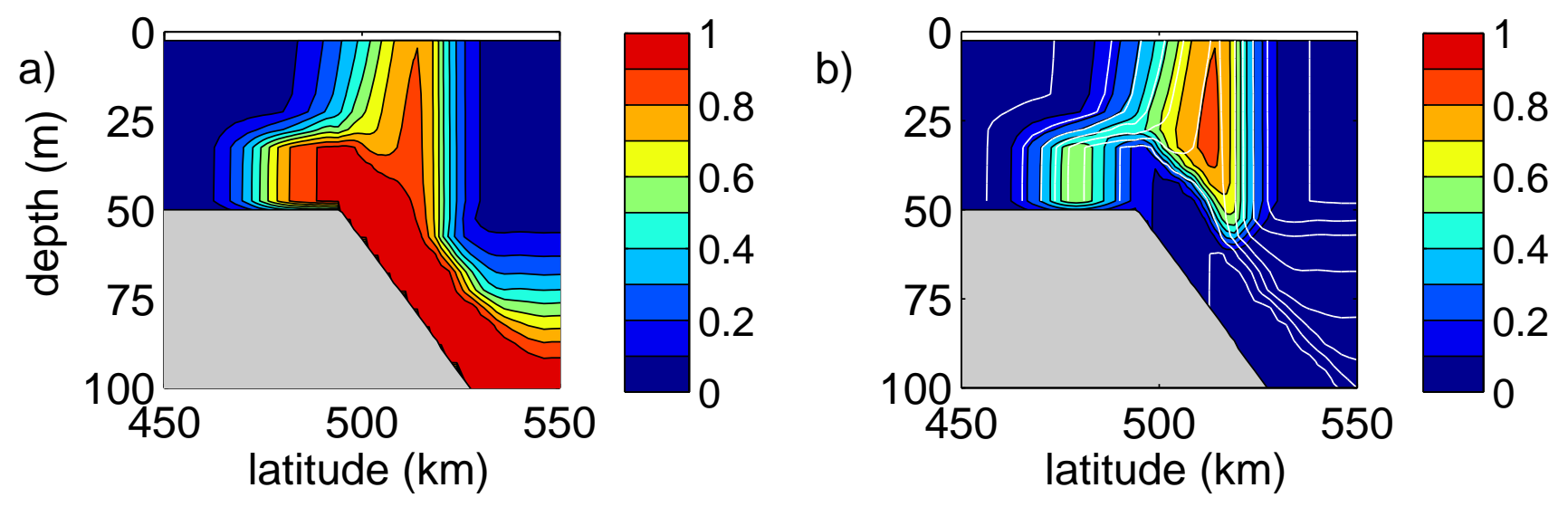

FIG. 14. a) Nutrient tracer on day 30; b) productivity tracer and salinity (white contours, contour interval 0.05) on day 30 . 